University of Nebraska - Lincoln

DigitalCommons@University of Nebraska - Lincoln

$11-2007$

\title{
Sedimentology and Stratigraphic Architecture of the Late Permian Betts Creek Beds, Queensland, Australia
}

Jonathan P. Allen

University of Nebraska-Lincoln, jallen19@bigred.unl.edu

Christopher R. Fielding

University of Nebraska-Lincoln, cfielding2@unl.edu

Follow this and additional works at: https://digitalcommons.unl.edu/geosciencefacpub

Part of the Earth Sciences Commons

Allen, Jonathan P. and Fielding, Christopher R., "Sedimentology and Stratigraphic Architecture of the Late Permian Betts Creek Beds, Queensland, Australia" (2007). Papers in the Earth and Atmospheric Sciences. 278.

https://digitalcommons.unl.edu/geosciencefacpub/278

This Article is brought to you for free and open access by the Earth and Atmospheric Sciences, Department of at DigitalCommons@University of Nebraska - Lincoln. It has been accepted for inclusion in Papers in the Earth and Atmospheric Sciences by an authorized administrator of DigitalCommons@University of Nebraska - Lincoln. 
Published in Sedimentary Geology 202:1-2 (November 15, 2007), pp. 5-34; doi: 10.1016/j.sedgeo.2006.12.010 ; Selected papers presented at the Eighth International Conference on Fluvial Sedimentology. Copyright (C) 2007 Elsevier B.V. Used by permission.

http://www.sciencedirect.com/science/journal/00370738

Published online January 8, 2007.

\title{
Sedimentology and Stratigraphic Architecture of the Late Permian Betts Creek Beds, Queensland, Australia
}

\author{
Jonathan P. Allen and Christopher R. Fielding \\ Department of Geosciences, 214 Bessey Hall, University of Nebraska-Lincoln, Lincoln, NE 68588-0340, USA \\ Corresponding author - J. P. Allen, fax 402 472-4917, email jallen19@bigred.unl.edu
}

\begin{abstract}
The Late Permian Betts Creek Beds form a succession of coal-bearing alluvial-coastal plain sediments in a basin marginal setting within the northeastern Galilee Basin, Queensland, Australia. The unit is $\sim 50-60 \mathrm{~m}$ in thickness at Porcupine Creek National Park where outcrop is laterally continuous for several kilometers. Eight facies have been identified within the formation and can be grouped into 2 facies associations: (A) channel deposits and (B) floodbasin deposits. The channel association consists of conglomerate (A1) and trough cross-bedded multistorey sandstone facies (A2), both interpreted as deposits of low-sinuosity river systems, tidally influenced fluvial channels (A3), interbedded sandstone and siltstone (A4) interpreted as the abandonment fill of the alluvial systems, and diamictite (A5) interpreted as debris flows. The floodbasin facies association is composed of sandy siltstone (B1; proximal-distal floodbasin), carbonaceous siltstone (B2; mire), and bioturbated siltstone (B3; estuarine) facies.

The overall sediment body architecture can be resolved into 6 unconformity-bounded cycles interpreted as sequences in the genetic sense, which are sheet-like in geometry and, in general, consist of amalgamated multistorey, multilateral braided fluvial deposits at the base overlain by extensive sheet-like overbank mudstones, carbonaceous shales, and coals. Sea-level change is interpreted as the primary control on the sequence architecture of the formation, while the internal stratigraphic architecture, however, varies between sequences and is a function of a combination of sea level, tectonic, and autogenic controls.
\end{abstract}

Keywords: alluvial architecture, Late Permian, Eastern Australia, sea-level change, cyclicity

\section{Introduction}

While the past ten years have seen remarkable progress and advances in our understanding of the major controls on the large-scale sediment body architecture of alluvial successions, these controls are still not clearly understood (Blum and Törnqvist, 2000). Outcrop, laboratory, and computer modeling studies have suggested that sea level, tectonics, and climate act as major controls on the architecture of alluvial successions (e.g. Shanley and McCabe, 1993; Mackey and Bridge, 1995; Olsen et al., 1995; Heller and Paola, 1996; and see Blum and Törnqvist, 2000, and Bridge, 2003, for reviews). However, analyses of the stratigraphic architecture of coal-bearing alluvial plain sequences are more limited. While some studies have highlighted the effects of sea level (Bohacs and Suter, 1997), tectonics (Fielding, 1987), and climate (Fielding and Webb, 1996; papers in Pashin and Gastaldo, 2004) on coal-bearing strata, few have successfully deconvolved signals of multiple controls within individual successions. 

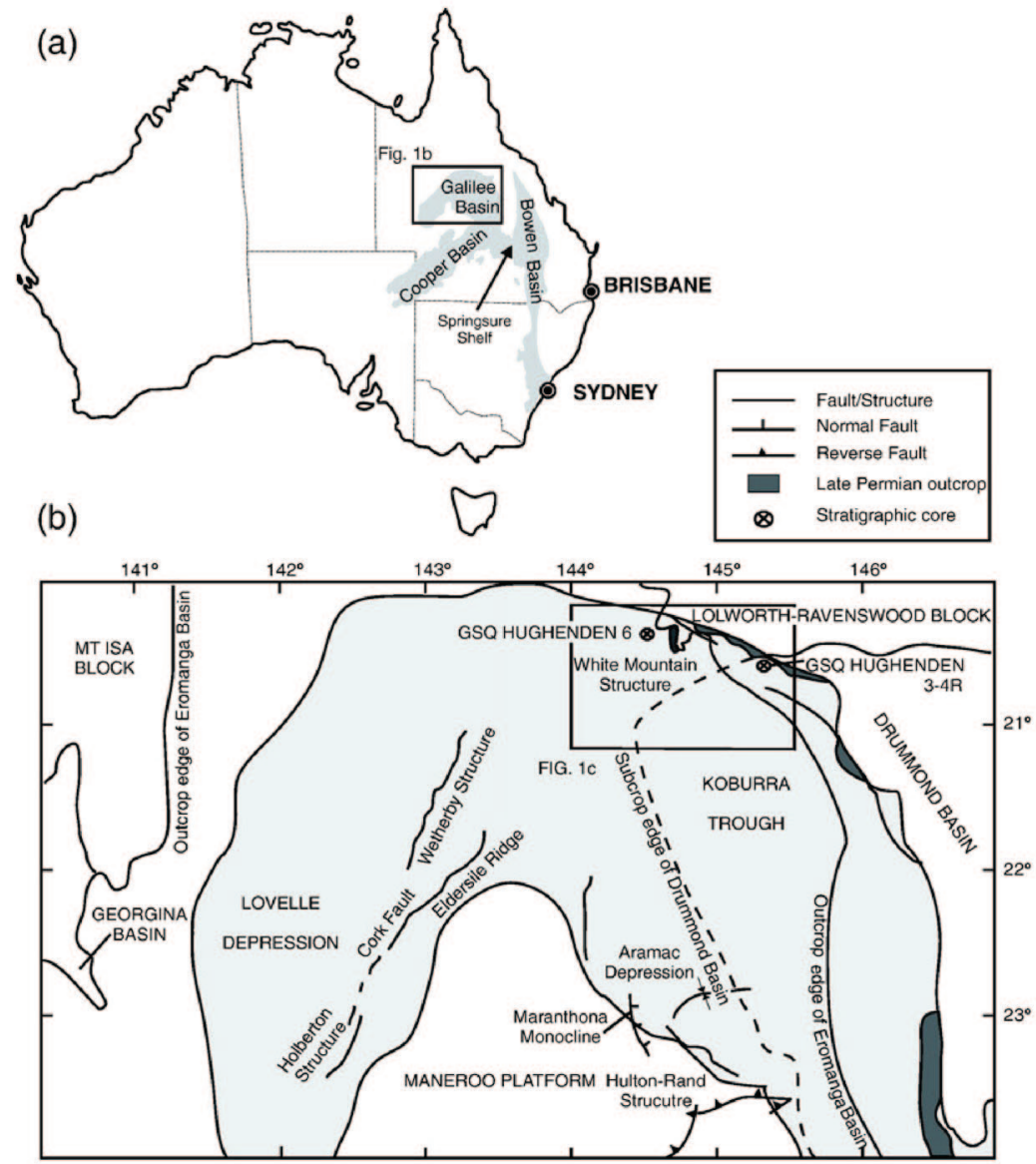

(c)

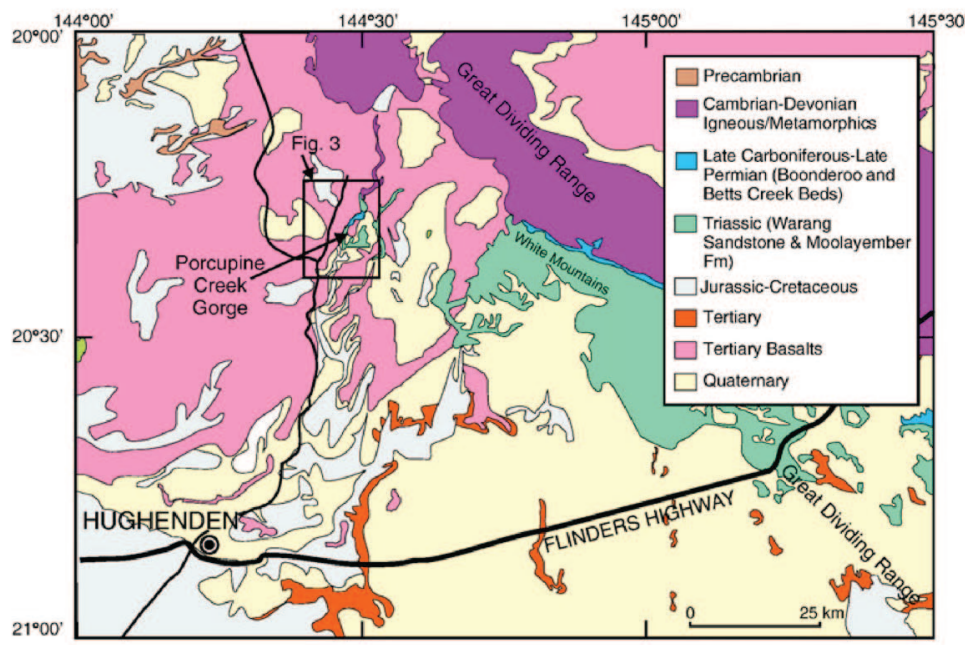

Figure 1. Location maps: (a) location of the Galilee Basin in relation to other major Permian basins in eastern Australia; (b) northern Galilee Basin detailing major structural features (modified from Hawkins and Green, 1993); (c) geology of the Hughenden area (modified from Vine and Paine, 1974).

The Betts Creek Beds in north-central Queensland, Australia provide an excellent opportunity to examine the interplay of both allogenic (sea level, tectonics, cli- mate) and autogenic controls on the sediment body architecture of coal-bearing alluvial plain systems. In this study, the effects of sea level and tectonics are dominant 


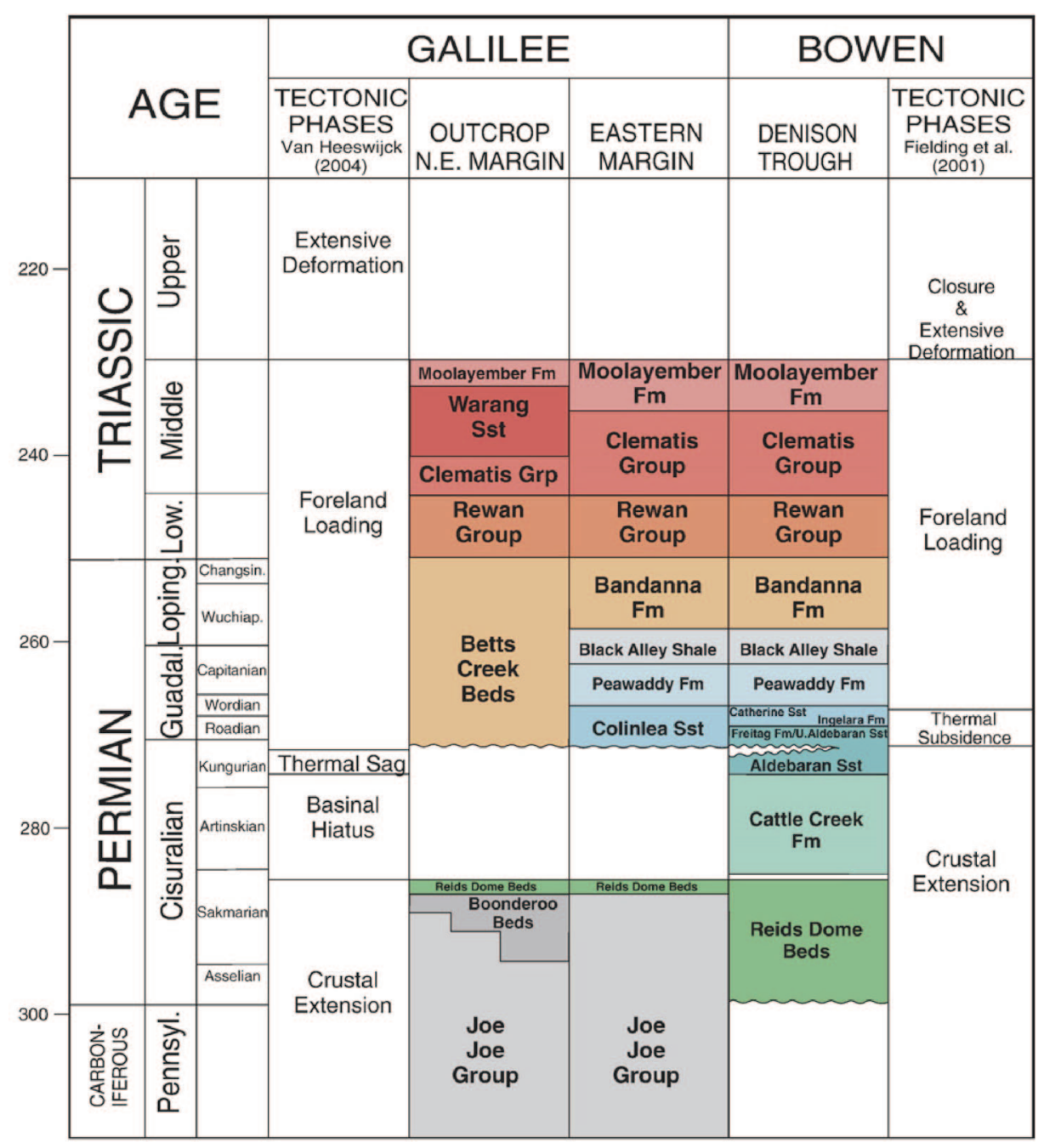

Figure 2. Revised lithostratigraphy for the northeastern and eastern margins of the Galilee Basin with the adjacent Bowen Basin. Tectonic phases are shown for the Galilee (from Van Heeswijck, 2004) and Bowen (from Fielding et al., 2001) Basins. Bowen Basin stratigraphy compiled from Lang et al. (2001), Fielding et al. (2001), and Anthony (2004).

controls on the sediment body architecture and the relationship between these and autogenic controls can be differentiated.

\section{Regional geology}

\subsection{Basin setting}

The Galilee Basin is a large intracratonic basin of Late Carboniferous to Triassic age located in central Queensland (Figure 1a). Basement comprises the Late Devonian-Early Carboniferous Drummond Basin to the east (Evans, 1980), the early Paleozoic metasedimentary and intrusive rocks of the Thomson Orogen in the center (Evans, 1980), and Precambrian to early Paleozoic metamorphic rocks west of the Cork Fault (Vine,
1976; Hawkins and Green, 1993). Much of the Galilee Basin is deeply buried beneath Jurassic-Cretaceous and Cenozoic sediments of the Eromanga Basin, with the only significant surface exposure along the eastern and northeastern basin margin (Figure 1a, b). Therefore, determining the lithostratigraphy of the basin is heavily dependent on limited subsurface data. The basin is divided into southern and northern regions at approximately $24^{\circ} \mathrm{S}$ (Hawkins and Green, 1993). This paper focuses on exposures near the northeastern margin of the Galilee Basin.

The northern Galilee Basin is bounded to the east by the Drummond Basin, to the north by the early Paleozoic Lolworth-Ravenswood Block, and to the west by the Precambrian Mount Isa Block and Georgina Basin (Evans, 1980; Scott and Hawkins, 1992; Hawkins and Green, 1993; Figure 1b). Two depressions, the Koburra 


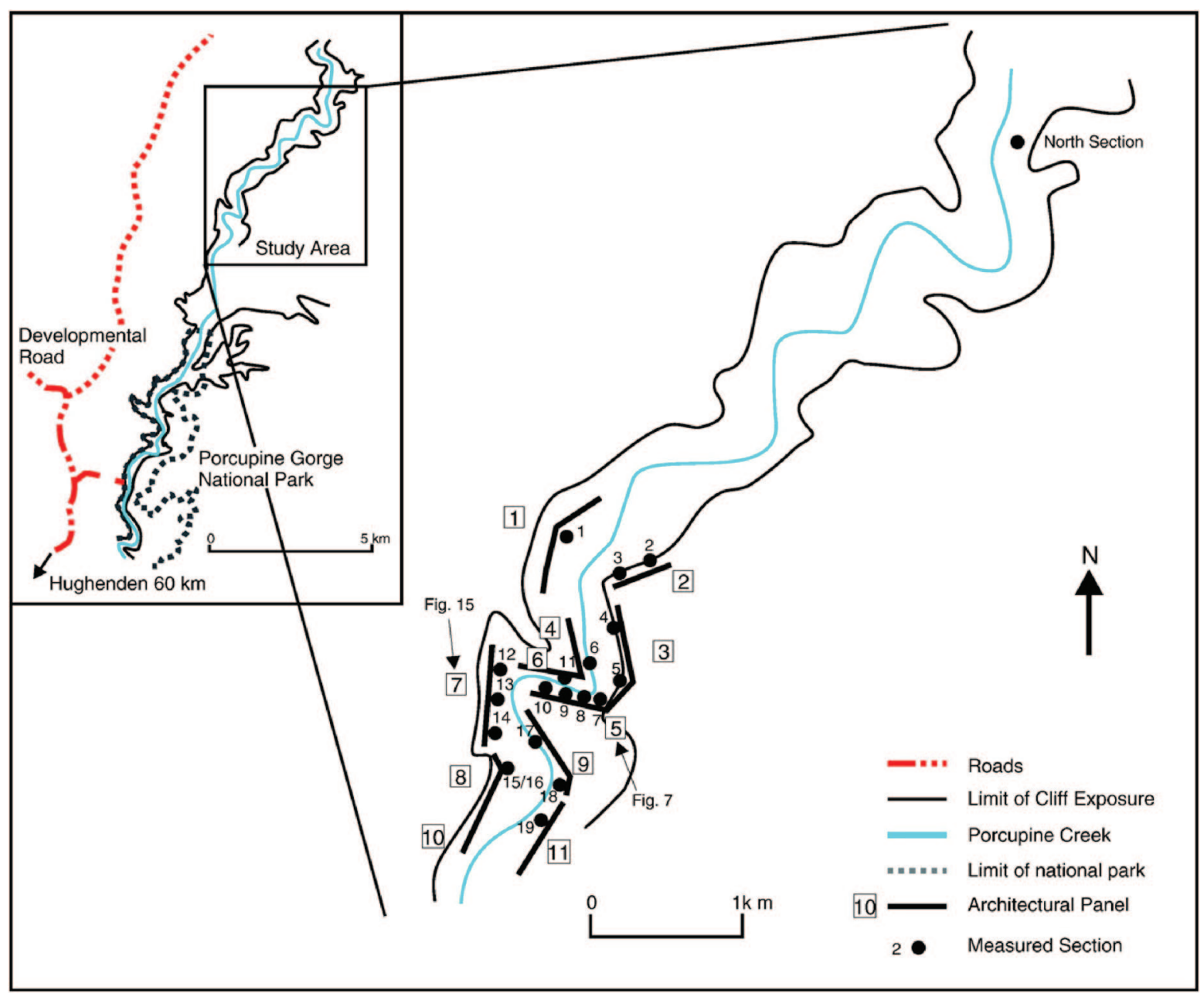

Figure 3. Location map showing study area within Porcupine Creek Gorge and locations of architectural panels and measured sections.

Trough and the Lovelle Depression, are separated by the early Paleozoic Maneroo Platform (Figure 1b).

In general, the Paleozoic basin fill can be divided into two sections (Evans, 1980; Figure 2). The Late Carboniferous to Early Permian basin fill is characterized by fluvial and lacustrine sediments of the Joe Joe Group, some of which are glaciogenic (Jochmus Formation and Boonderoo Beds). The late Early Permian was a time of widespread peat development represented by the Aramac Coal Measures. The basin experienced a period of nondeposition and/or gentle uplift (Evans, 1980) before the accumulation of widespread fluvial and coal deposits of the Betts Creek Beds and correlatives (Vine, 1976; Evans, 1980). During the Late Permian, sediments from the Bowen Basin spilled across the Springsure Shelf into the Galilee Basin (Fielding et al., 2001), and may have buried the bounding ridges, thereby connecting not only the Bowen and Galilee Basins, but also the Cooper Basin (Hawkins, 1978). Triassic strata in the basin are dominantly fluvial (Rewan Group, Warang and Clematis
Sandstones, and Moolayember Formation; Hawkins and Green, 1993).

The Galilee Basin fill was initially regarded as entirely non-marine (Vine and Paine, 1974; Vine, 1976), but Evans (1980) later suggested that marine conditions entered the southern Koburra Trough during the Late Permian. Furthermore, Scott and Hawkins (1992) and Hawkins and Green (1993) recognized bioturbated paralic facies along the eastern margin which they considered equivalent to the Peawaddy Formation of the Denison Trough. The present study recognizes several horizons of bioturbation and indications that paralic sedimentation extends farther northward along the basin margin.

\subsection{Tectonic and structural setting}

There have been several interpretations of the structural evolution of the Galilee Basin including: (1) a pull-apart basin formed by shearing along the north- 
Table 1. Summary of the general characteristics and interpretation of the lithofacies for the Betts Creek Beds

\begin{tabular}{|c|c|c|c|c|c|}
\hline $\begin{array}{l}\text { Association/ } \\
\text { Facies }\end{array}$ & Lithology & Sedimentary structures & Biota & Geometry & Interpretation \\
\hline \multicolumn{6}{|c|}{ A-Channel deposits } \\
\hline A1 & $\begin{array}{l}\text { Poorly sorted, clast- } \\
\text { supported, polymictic, } \\
\text { cobble conglomerate }\end{array}$ & $\begin{array}{l}\text { Trough cross-bedding, } \\
\text { scour surfaces, } \\
\text { clast imbrication }\end{array}$ & None recorded & $\begin{array}{l}\text { Extensive sheet } \\
\text { geometry, paleoflow } \\
\text { to } 142^{\circ}\end{array}$ & $\begin{array}{l}\text { Low-sinuosity } \\
\text { alluvial channels }\end{array}$ \\
\hline A2 & $\begin{array}{l}\text { Medium- to very } \\
\text { coarse-grained } \\
\text { sandstones }\end{array}$ & $\begin{array}{l}\text { Trough cross-bedding, } \\
\text { scour surfaces, flat } \\
\text { lamination, ripple } \\
\text { cross-lamination, parting } \\
\text { lineation, convolute } \\
\text { bedding, load casting }\end{array}$ & $\begin{array}{l}\text { Glossopteris, } \\
\text { Vertebraria, } \\
\text { Calamites }\end{array}$ & $\begin{array}{l}\text { Extensive sheet } \\
\text { geometry, incised } \\
\text { lateral margins, } \\
\text { paleoflow to } 192^{\circ}\end{array}$ & $\begin{array}{l}\text { Low-sinuosity } \\
\text { alluvial channels }\end{array}$ \\
\hline $\mathrm{A} 3$ & $\begin{array}{l}\text { Medium- to very } \\
\text { coarse-grained } \\
\text { sandstones }\end{array}$ & $\begin{array}{l}\text { Trough cross-bedding, } \\
\text { bidirectional/bimodal } \\
\text { cross-bedding, flat } \\
\text { lamination, ripple } \\
\text { cross-lamination, } \\
\text { wave ripples }\end{array}$ & $\begin{array}{l}\text { Thalassinoides } \\
\text { and Planolites } \\
\text { burrows }\end{array}$ & $\begin{array}{l}\text { Sheet geometry, } \\
\text { paleoflow to } 188^{\circ}\end{array}$ & $\begin{array}{l}\text { Tidally influenced } \\
\text { alluvial channels }\end{array}$ \\
\hline A5 & $\begin{array}{l}\text { Clast-rich sandy } \\
\text { diamictite, basement, } \\
\text { volcanic, and } \\
\text { intraformational clasts }\end{array}$ & $\begin{array}{l}\text { Massive unstratified, } \\
\text { rare clast imbrication } \\
\text { and crude bedding }\end{array}$ & $\begin{array}{l}\text { Rare macerated } \\
\text { plant material }\end{array}$ & $\begin{array}{l}\text { Confined to } \\
\text { channel forms }\end{array}$ & Debris flows \\
\hline \multicolumn{6}{|c|}{ B - Floodbasin deposits } \\
\hline B1 & $\begin{array}{l}\text { Interbedded to } \\
\text { interlaminated } \\
\text { sandstone and siltstone }\end{array}$ & $\begin{array}{l}\text { Small-scale cross-stratifi- } \\
\text { cation, ripple cross-lami- } \\
\text { nation, interlamination } \\
\text { structures, convolute } \\
\text { bedding, load casting }\end{array}$ & $\begin{array}{l}\text { Planolites burrows, } \\
\text { Glossopteris, } \\
\text { Vertebraria, } \\
\text { Calamites }\end{array}$ & $\begin{array}{l}\text { Overall extensive } \\
\text { sheet geometry, small } \\
\text { channel forms, some } \\
\text { depositional dips }\end{array}$ & Overbank \\
\hline
\end{tabular}

eastern and eastern margin of Australia (Evans, 1980), (2) a pericratonic basin (Vine, 1976; Veevers et al., 1982), (3) a basin formed by convective downwelling and regional downwarp (Middleton and Hunt, 1989), and (4) a foreland basin (De Caritat and Braun, 1992). Subsequently, Van Heeswijck (2004) re-evaluated the structural development of the Drummond and Galilee Basins and concluded that the development of the Galilee Basin was similar to the development of the adjacent and coeval Bowen Basin (Van Heeswijck, 2004). Fielding et al. (2001) developed a paleogeographic synthesis for the Bowen-Gunnedah-Sydney Basin System (BGSBS) in which major events and sequences were found to be synchronous from north Queensland to southernmost New South Wales. The BGSBS is con- sidered to have developed sequentially by crustal extension (Late Carboniferous-Early Permian), passive thermal subsidence (mid-Permian), and then foreland crustal loading (Late Permian-Middle Triassic) in response to pulsed thrust sheet propagation during the Hunter-Bowen Event (Fielding et al., 2001). Van Heeswijck (2004) recognized a similar three-phase history within the Galilee Basin, concluding that the Galilee and Bowen basins were closely related in their development (Figure 2).

\subsection{Regional geology of the Betts Creek Beds}

The Betts Creek Beds (BCB) and their correlatives represent the final development of coal-forming condi- 
tions within the Galilee Basin. Age control for the Galilee Basin relies on palynological and plant macrofossils (White, in press; Evans, 1967). Evans (1967) proposed palynological stages for eastern Australia, placing the BCB in his Stage 5 (late Early Permian-Late Permian). Nonetheless, several authors contend that Stage 5 represents only the Late Permian (Hawkins, 1978; Hawkins and Green, 1993), and this is the view taken in this paper.

The BCB vary greatly in thickness, reaching a maximum thickness of $390 \mathrm{~m}$ (Evans, 1980). Hawkins (1976) described the entire succession as an eastward-thickening lens, thinning rapidly westward and to the north. The BCB crop out in the Hughenden area and in Porcupine Creek (Galah) Gorge (Figure 1c, 3), where the maximum thickness is $\sim 60 \mathrm{~m}$. The only published study of the BCB outcrop was part of a mapping survey in which the BCB were interpreted as fluvial and paludal sediments, with alluvial fan, piedmont, and mudflow deposits (Vine and Paine, 1974). The present study focuses on the BCB sensu stricto in Porcupine Creek Gorge (Figure 3).

\section{Study area and methods}

The BCB are well exposed for several kilometers in $>75 \mathrm{~m}$ high cliffs along Porcupine Creek Gorge $\sim 65 \mathrm{~km}$ northeast of Hughenden in northern Queensland, Australia (Figure 3). The nature of the exposures is ideal for a three-dimensional architectural study. The area studied as well as the location of cliff exposures (referred to as panels) used for architectural analysis and measured sections are shown in Figure 3. Photomosaics were taken for all exposures in order to map out bounding surfaces and large-scale architectural elements. Twenty, detailed measured sections were logged at the centimeter scale and the resulting data were coupled to the corresponding photomosaics. Major bounding surfaces identified first in photomosaics and measured sections were walked out in the field in order to correlate surfaces between outcrop panels and accurately describe the geometry of the formation. A laser rangefinder was used to delineate major bounding surfaces and to measure thicknesses of major units that were inaccessible. Regional dip, however, allowed the entire formation to be investigated and detailed at some point along the outcrop belt. Paleocurrent measurements and hand specimens from a lithologic suite representative of the $\mathrm{BCB}$ were also collected.

\section{Lithofacies and architectural elements}

Eight lithofacies are recognized within the BCB (Table 1 ). These facies have been assigned to two associations that reflect the architecture and major depositional environments of the $\mathrm{BCB}$ and are $(\mathrm{A})$ channel deposits and (B) floodbasin deposits.

Eight architectural elements and two higher-order lithosomes have been identified within the succession of the BCB (Table 2). The two higher-order lithosomes, channel and overbank, were established in order to avoid confusion within the architectural classification. Architectural features are observed at different scales and orders, and should therefore have a hierarchy for their classification, just as bounding surfaces have a hierarchy that establishes the scale of feature that they enclose (channel-belt, channel, macroform, etc.). Therefore, lithosomes are defined as architectural features that are made up of architectural elements, which in turn are composed of smaller, internal features.

Architectural elements are distinguished by a variety of characteristics including bounding surfaces, lithofacies composition, geometry, vertical and lateral associations, and paleocurrent distributions. Bounding surfaces were assigned a numerical rank after Miall (1996). Bounding surfaces of first-and second-order have not been detailed on any of the architectural panels, because they cannot be distinguished. The criteria for recognition of architectural elements are summarized in Figure 4 and Table 2, and were adapted and modified after Miall (1985, 1988, \& 1996). For ease of comparison between this study and others, elements have been given codes in the fashion of Miall (1996). Several elements, however, warranted a different code from those set out by Miall (1996) and will be discussed below, along with modified elements. Those elements that have already been defined (DA, LA, SF, OF, LE, CS) will not be detailed further.

\subsection{Channel (CH) lithosome}

Channel lithosomes as discussed above contain withinchannel elements. $\mathrm{CH}$ lithosomes are not clearly defined within the study area and only a few channel margins have been observed. This lack of definition may be due to the abundance of outcrop exposure roughly parallel to paleoflow. It is not expected that channel margins would be observed with such orientations; instead a sheet-like channel geometry is observed. Where outcrop orientations are normal to paleoflow, several channel margins can be delineated, but only two architectural panels $(2,5)$ are observed with this orientation. Where 
Table 2. Classification and description of architectural elements recognized within the Betts Creek Beds

\begin{tabular}{lll}
\hline $\begin{array}{l}\text { Architectural } \\
\text { Element }\end{array}$ & $\begin{array}{l}\text { Facies } \\
\text { Composition }\end{array}$ & Geometry \\
\hline $\begin{array}{l}\text { Channel lithosome } \\
\text { Channel }(\mathrm{CH})\end{array}$ & A1, A2, B1, B3 & $\begin{array}{l}\text { Variable scale from } 20 \text { to }>400 \text { m wide } \\
\text { and } 1-7 \text { m deep. }\end{array}$
\end{tabular}

Bounding surfaces

\section{Within-channel elements}

Nested channel $\quad$ A2, A3
fill element (NC)

fill element (NC)

Sheet-like complexes extending $>1 \mathrm{~km}$ laterally, and 1-11 m thick (commonly $<6 \mathrm{~m}$ ). Individual NC tabular or lenticular elements range from 10 to $>500 \mathrm{~m}$ long and 1-5 $\mathrm{m}$ thick.

Downstream-accretion A2 macroform (DA)

Lateral-accretion A2

macroform (LA) A2

Channel fill (CF) A4, A5

Scour fill (SF)

$\mathrm{A} 1, \mathrm{~A} 2$

Overbank lithosome

Overbank fines (OF) B1, B2, B3

\section{Overbank elements}

Levee (LE)

B1

Crevasse splay (CS) A2
Wedge-shaped body $2 \mathrm{~m}$ thick and $>40 \mathrm{~m}$ long. Overlies OF element, overlain by NC elements.

Tapered wedge-shaped bodies up to $80 \mathrm{~m}$ wide and 1-6 $\mathrm{m}$ thick. Overlain by NC elements.

Variable scale from $20-50 \mathrm{~m}$ wide and 2-7 $\mathrm{m}$ deep. Overlie NC and OF elements, overlain by $\mathrm{CH}$ or $\mathrm{NC}$ elements.

Lenticular bodies extending up to $50 \mathrm{~m}$ long and $2 \mathrm{~m}$ deep. Concentrated at the base of a unit.

Extensive sheet-like bodies, extending > 2000 m laterally, 0.1-2.5 m thick. Overlain by $\mathrm{CH}$ and $\mathrm{NC}$ elements, associated with LE and CS elements

Sheet-like to lenticular bodies $40-100 \mathrm{~m}$ long with internal inclined accretionary layers extending $<50 \mathrm{~m}$ down-dip, 1-5 m thick, passing laterally into OF elements. Commonly associated with $\mathrm{CS}$ and small-scale $\mathrm{CH}$ elements. Overlain by NC elements.

Lenticular bodies, extending $<40 \mathrm{~m}$ laterally and 0.1-2 m thick. Associated with LE and OF elements. Erosively overlain by NC elements.
Basal 5th order bounding surfaces.

Erosively based with concave-up margins. Most margins are not clearly defined within the study area.

Bound by 4 th order surfaces that may coalesce into 5th order surfaces. Erosively irregular/planar to slightly concave bases, in some places channel-form. Upper surfaces usually erosively irregular or planar, flat or slightly convex where not eroded. Internal 3rd order surfaces.

Bound by 4 th order surfaces with dipping internal 3rd order surfaces. Planar to slightly concave base, erosively irregular to planar tops.

Bound by 4 th order surfaces with dipping internal 3rd order surfaces. Planar to slightly concave base, erosively irregular to planar tops.

Bound by 5 th or 4 th order basal surfaces and 5 th order upper surfaces. Sharp, erosive, concave (channel-form) bases, erosionally irregular, concave upper surfaces.

Erosively irregular to concave basal surface, erosively planar to gradational top surface.

Surfaces usually planar or gently concavo-convex, sharp to transitional bases. Tops sharp to erosionally irregular bounded by 5 th or 4 th order surfaces.

Bound by 4th order surfaces. Sharp, planar non-erosive bases. Interbedded sandstone and siltstone pass down depositional dip into interlaminated sandstone and siltstone.

Top usually truncated by concave or flat surfaces.

Bound by 4th order surfaces. Erosively sharp, planar base, with planar to undulatory tops.

Architectural elements adapted and modified from (Miall, 1985 \& 1996).

channel margins are exposed, they probably represent the temporary margins of migrating channels within a wide channel belt.

\subsection{Nested channel fill (NC)}

This element broadly equates to the SB element of Miall (1996), and is composed of sediments of Facies A2.

\subsection{Channel fill (CF)}

Two variations of this element are recognized within the $\mathrm{BCB}$. The most common $\mathrm{CF}$ elements are infilled with fine-grained sediments of Facies A4 and are interpreted as representing channels undergoing abandonment. This variant of $\mathrm{CF}$ element is similar to the $\mathrm{FF}(\mathrm{C})$ element of Miall (1996). The other variant of CF 


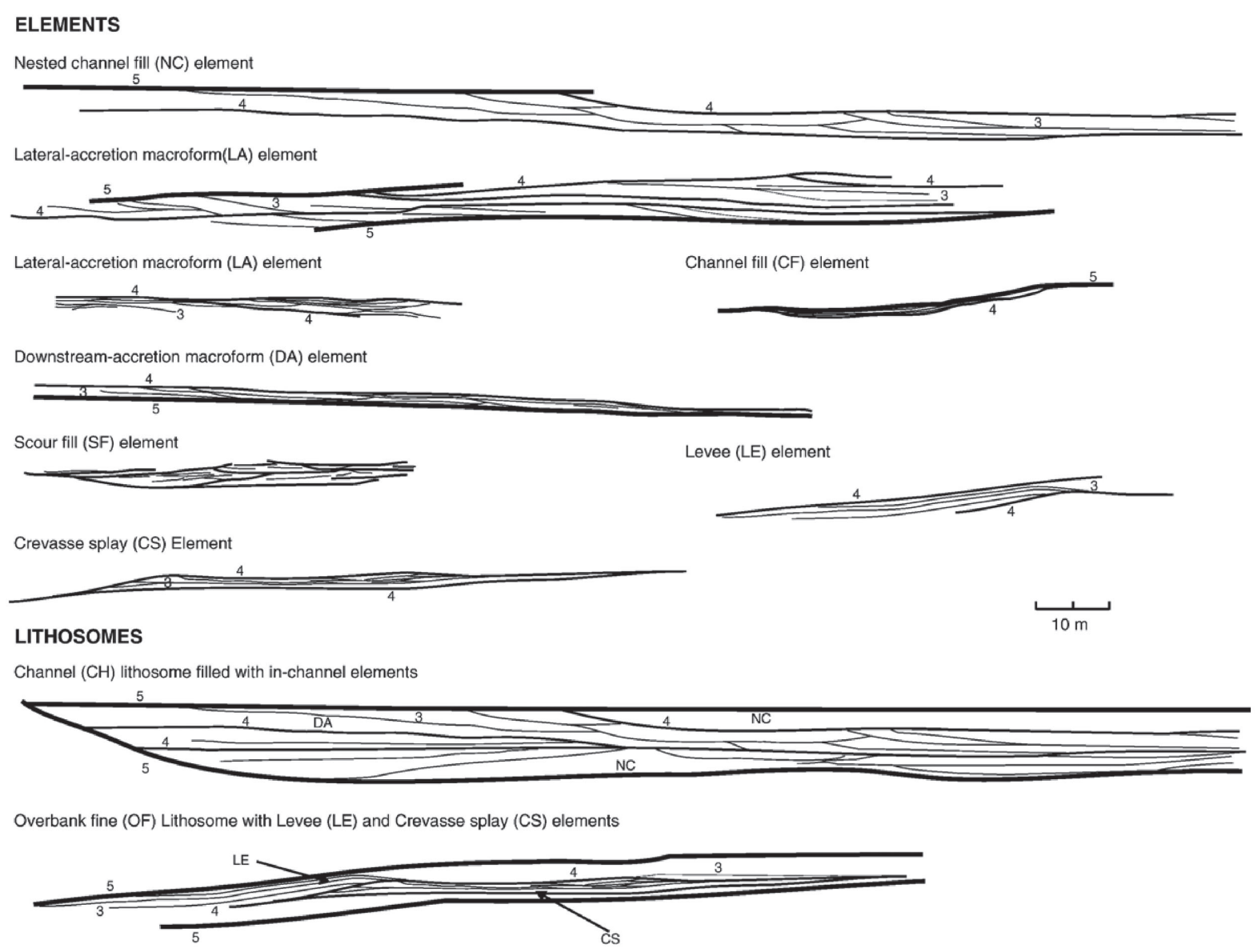

Figure 4. Architectural elements and lithosomes recognized within the Betts Creek Beds. Cross-sections are the same horizontal and vertical scale. Bounding surfaces are numbered according to rank. Element classification after (Miall, 1988) and (Miall, 1996).

element is composed of volcaniclastic sediments of Facies A5, interpreted as channels that were occupied by debris flows during periods of explosive volcanism (see below for interpretation). This variant of CF element is also characterized by broader, shallower channels.

\section{Facies and architectural analysis}

\subsection{Facies association A - channel deposits}

\subsubsection{Facies A1 - conglomerate}

Facies A1 consists of extraformational, clast-supported, polymictic, cobble conglomerate. Clasts reach $80 \mathrm{~cm}$ in a-axis length, but average $8 \mathrm{~cm}$. They are poorly sorted, subrounded to rounded, platy to spheroidal, and composed predominantly of quartz, gneiss, granite, and tuff. The matrix is coarse, sub-angular, quartz sand. Facies A1 unconformably overlies the Late Carboniferous-Early Permian Boonderoo Beds and is restricted to the basal part of the formation. Upper con- tacts are sharp and the facies is overlain by either Facies A2 or B1. The conglomerate fines upwards from a cobble conglomerate to interbedded very coarse sandstone and pebble conglomerate.

Facies A1 is characterized by massive to crude bedding arranged in sheet-like to lenticular bodies with upper and lower surfaces defined by SF elements with localized trough cross-bedding. Several locations where Facies A1 occurs appear to be composed of a mosaic of coalesced SF elements. Rare $\mathrm{CH}$ elements are also observed. Trough cross-bedding is as much as $0.8 \mathrm{~m}$ thick, but commonly $<0.4 \mathrm{~m}$. Paleocurrent directions from trough cross-beds trend southeastward $\left(\right.$ mean $=142^{\circ}$; Figure 5a). Imbricated large clasts in the basal portion of the conglomerate indicate paleoflow to the south (Figure $5 b$ ), slightly oblique to the paleoflow indicated by trough cross-bedding.

5.1.1.1. Interpretation - The sheet-like geometry, abundance of SF elements with subordinate trough cross-bedding, and relatively low dispersion of paleo- 
current data are highly compatible with deposition within low-sinuosity alluvial channels. Facies A1 has many characteristics that have been widely recognized in modern and ancient gravelly braided streams (Smith, 1974, 1990; Boothroyd and Ashley, 1975; Miall, 1977; Rust, 1984; Ramos et al., 1986).

The bulk of Facies A1 represents deposits from longitudinal gravel bars and sheets in a relatively shallow setting marked by high flow velocities (cf. Williams and Rust, 1969; Smith, 1974; Rust, 1978; Ramos et al., 1986; among others). Trough cross-bedding records the avalanching of clasts on the downward or lateral flanks of longitudinal bars under diverging flow (Rust, 1984; Collinson, 1996). Associated coarse- to medium-grained sandstones were deposited from the lateral margins of bars during falling-stage flow (cf. Massari et al., 1993). Where trough cross-bedding is not associated with bar deposits, it is interpreted as three-dimensional dunes migrating under low flow regimes.
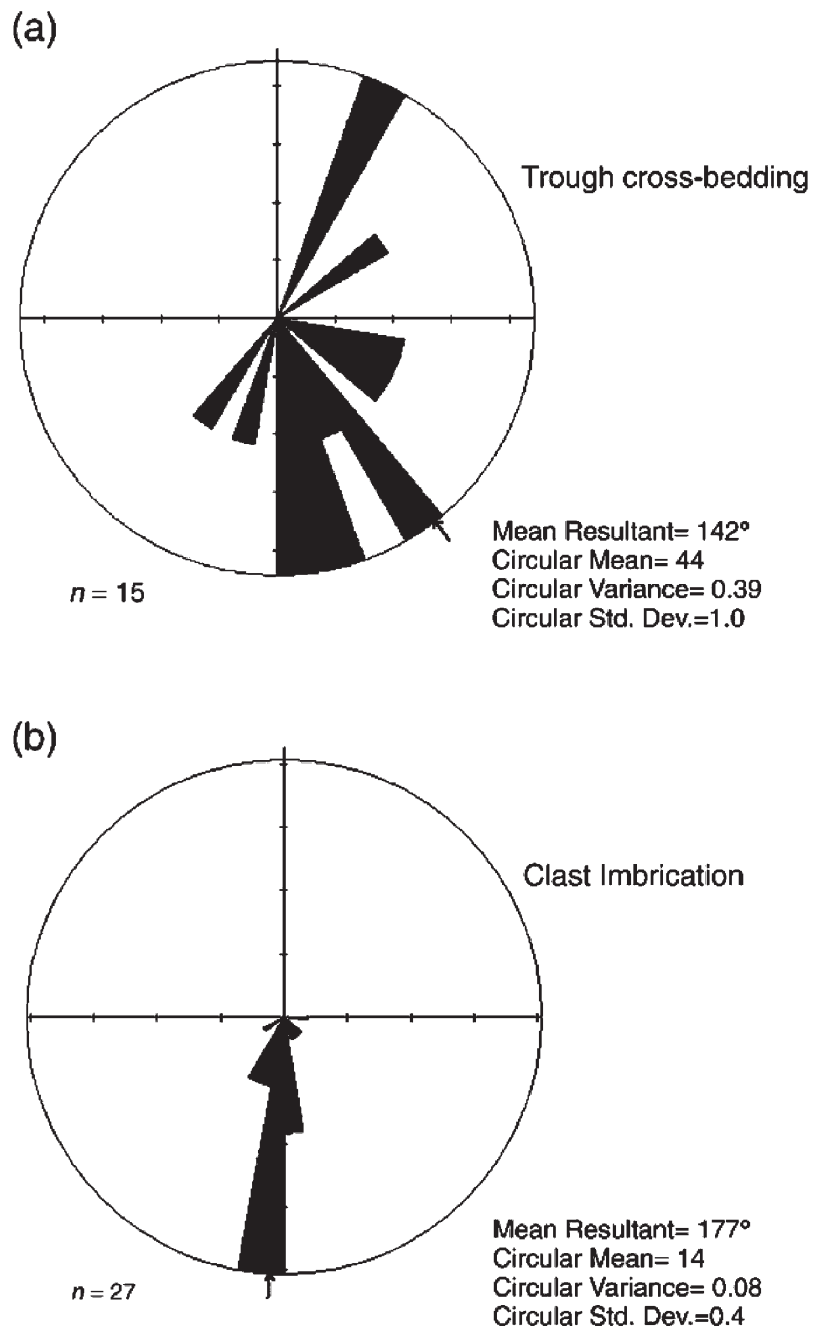

Figure 5. Rose diagrams summarizing paleocurrent data for Facies A1 collected from (a) trough cross-beds, (b) clast imbrication.
Abundant SF elements are attributed to the complex pattern of rapidly changing channels and bars, which are characteristic of gravelly braided streams. Many of the bar deposits have scoured upper and lower surfaces suggesting that the deposits originate from several bars rather than a single depositional event (cf. Ramos et al., 1986). They are therefore considered compound bars constructed in channels wherein flows competent enough to move coarse bedload are relatively frequent (Smith, 1974; Karpetta, 1993).

\subsubsection{Facies A2 - coarse- to medium-grained, multistorey sandstone}

Facies A2 is contained within coarse- to mediumgrained sandstone bodies up to $11 \mathrm{~m}$ thick. These bodies are erosionally based and sheet-like in overall geometry. Basal contacts of sandstone bodies are sharp and undulatory 5 th order surfaces, with up to $8 \mathrm{~m}$ or more of relief, and can be traced over the entire study area $(>7 \mathrm{~km})$. These contacts are commonly lined with well-rounded quartz, siltstone, and tuff clasts averaging $6 \mathrm{~cm}$ in length. Pervasive soft-sediment deformation, commonly in the form of load casts and convolute bedding (Figure 6a), is also common along basal contacts. Upper contacts of sandstone bodies are mostly sharp 5th order surfaces, although some are gradational. Upper contacts are locally marked by interbeds of fine-grained, ripple cross-laminated or flat-laminated sandstone and siltstone. Where lateral sandstone-body margins are observed, they are wedge-shaped pinchouts that are incised as much as $5 \mathrm{~m}$ into previously deposited sediments, commonly of Facies B1 (Figure $6 \mathrm{~b})$. Interbeds of fine-grained sandstone and siltstone appear at the margins of sandstone bodies and bedding becomes increasingly undulatory and deformed. Overall vertical grain-size variation is typically irregular or minimal, although some sandstone bodies show a slight (? crude) upward fining.

Most sandstone bodies in the BCB are multistorey, displaying well-defined storeys, although they become more amalgamated and composite in the upper two-thirds of the formation. Storeys are typically $<3 \mathrm{~m}$ in thickness, but locally reach up to $10 \mathrm{~m}$, and can be traced for hundreds of meters laterally. Storey boundaries are typically sharp and undulatory, but some are erosional channel surfaces with as much as $8 \mathrm{~m}$ of relief (commonly $<3 \mathrm{~m}$ ) that incise into underlying fine-grained sediments as well as other storeys (Figure 6c). In some instances, overlying storeys may truncate and completely cut out underlying storeys. Basal storey boundaries are lined with granule or pebble lags. Some storeys are separated from each other by $<60 \mathrm{~cm}$ of fine-grained sediments of Facies B1. 

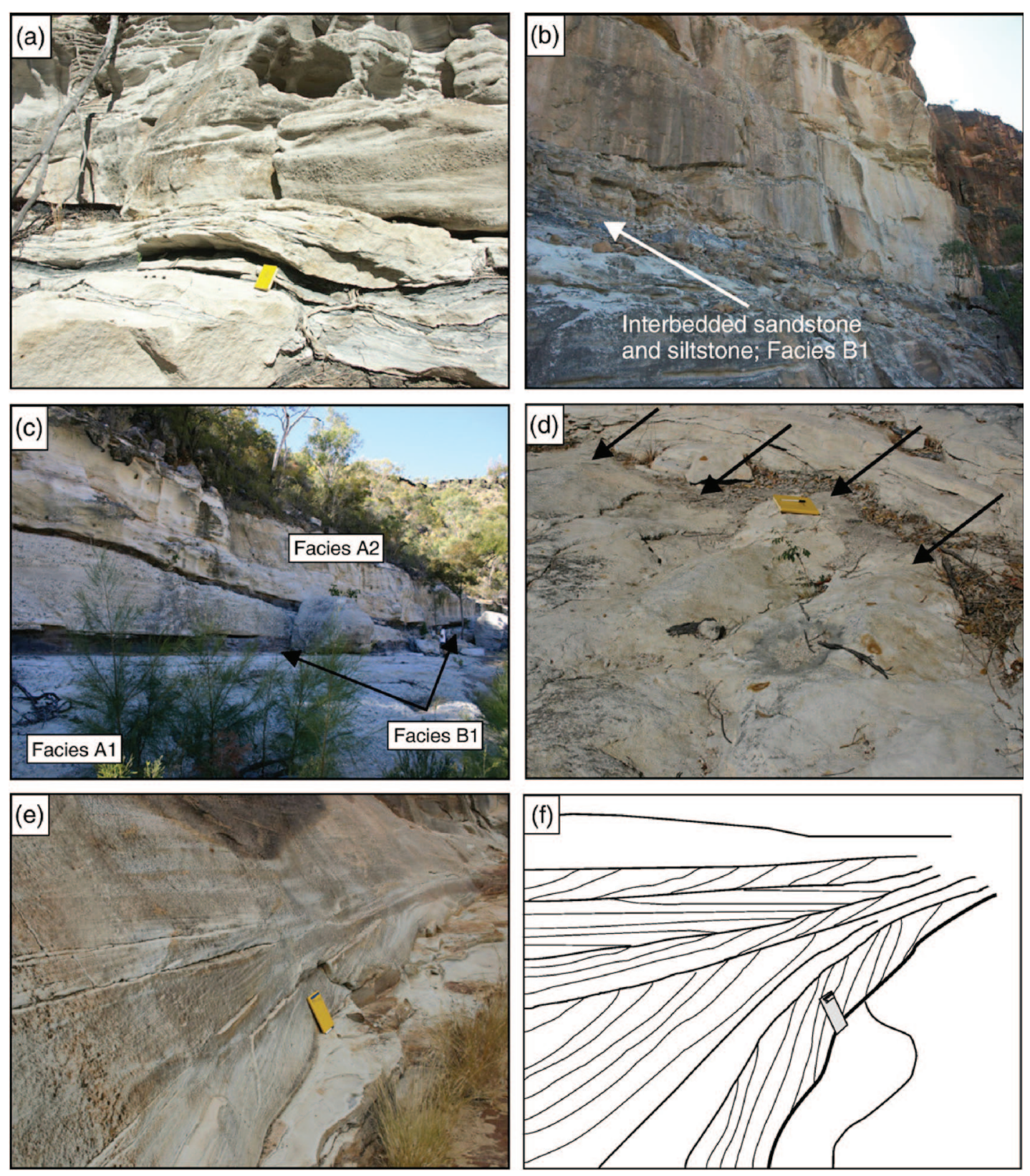

Figure 6. Facies A2 and A3. (a) Sandstone bed (Section 7) showing strong soft-sediment deformation (convolute bedding and loading). Note sharp, undulatory lower contact with underlying sediments of Facies B1. Notebook $=20 \mathrm{~cm}$. (b) View of Section 1 showing the amalgamated nature of composite sandstone bodies within the upper part of the formation. Lateral pinchout (arrow) into Facies B1. Note the complex interbedded nature of Facies B1 near sandstone body margin. Section oblique to paleoflow. Section approximately 15 m. (c) Multistorey sandstone (Panel 3) separated by Facies B1, B2. Note the channel form truncating an underlying parting of Facies B1 and cutting out an underlying sandstone storey. Section oblique to paleoflow. Geologist $=1.9 \mathrm{~m}$. (d) Bedding plane exposure (Section 14) showing symmetrical wave ripples from the top of a Facies A3 storey. Ripple crests are arrowed. Wavelengths approximately $50 \mathrm{~cm}$. Notebook $=20 \mathrm{~cm}$. (e) View of Section 19. Notebook $=20 \mathrm{~cm}$. (f) Line drawing interpretation of (e) detailing herringbone cross-stratification.

The internal architecture of the sandstone storeys consists predominantly of stacked, tabular or lenticular NC elements arranged in a multistorey and multilateral framework. Individual NC elements are typically 1-5 m in thickness, several hundred meters long, and are de- fined by erosional, slightly concave-up 4th order surfaces that may coalesce into higher 5th order surfaces. Basal surfaces are planar in most cases, but in several architectural panels bases exhibit channel-form geometries. Because only two architectural panels are oriented 

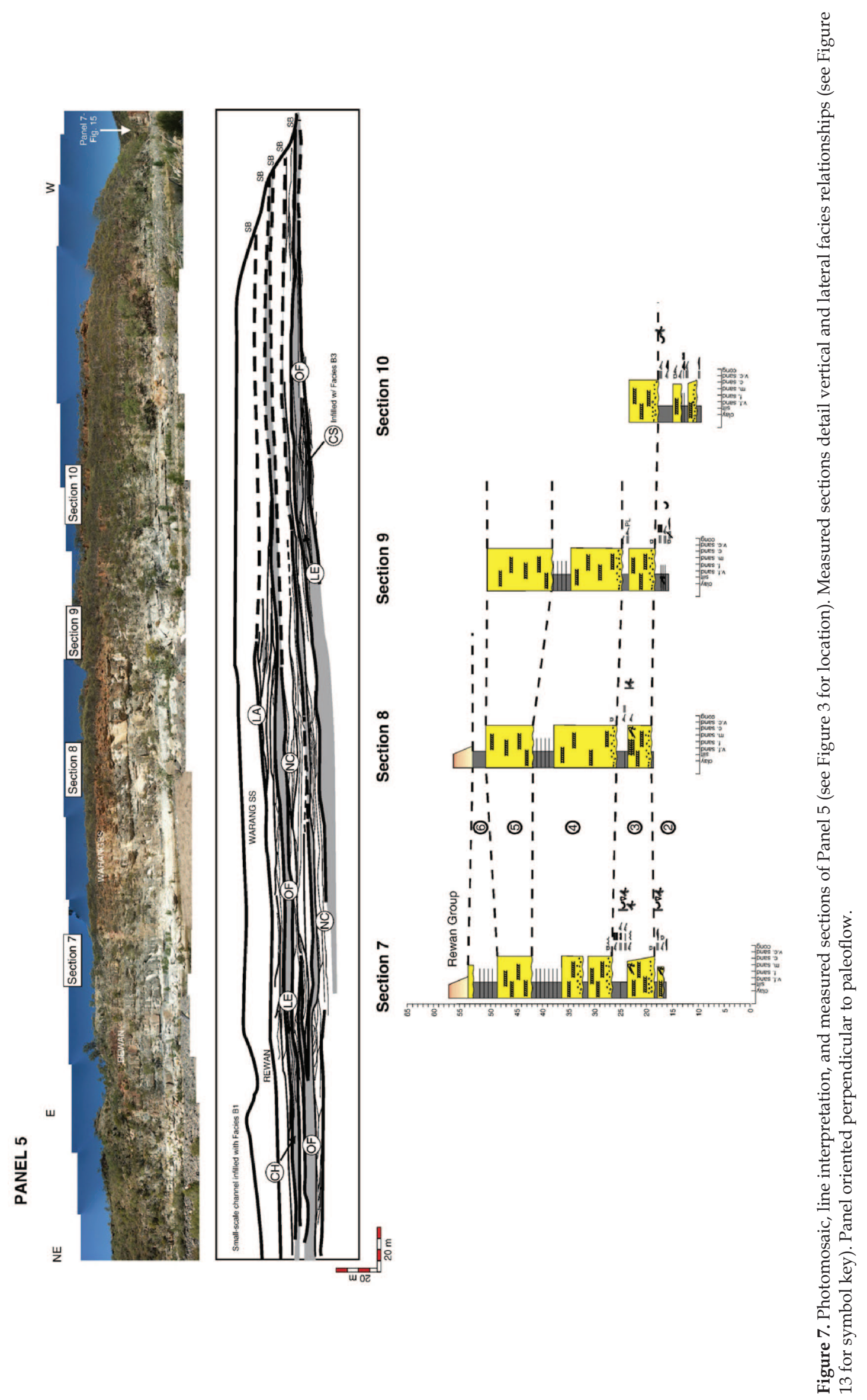


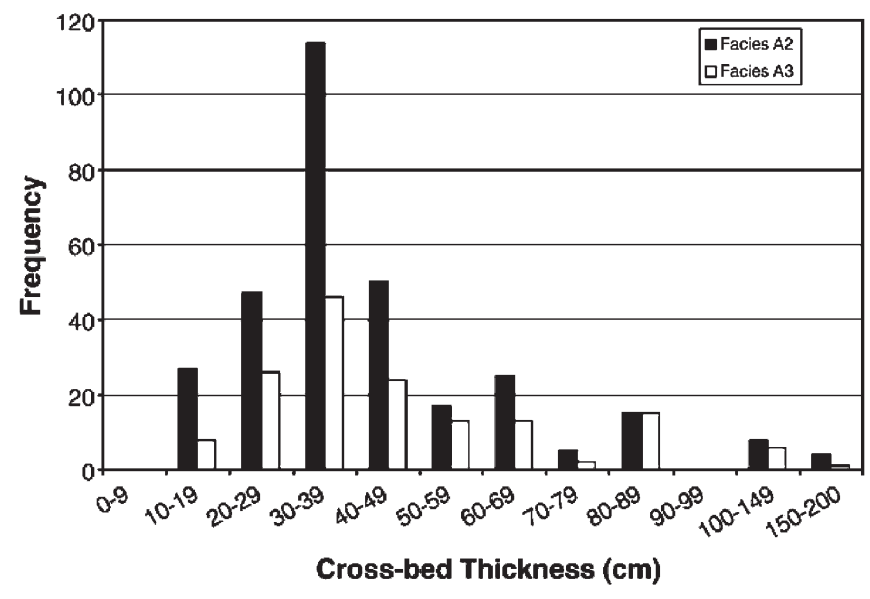

Figure 8. Cross-bed thicknesses of Facies A2 and A3.

normal to paleoflow, lateral dimensions of NC elements are not easily discerned, but where observed these elements range from 50-150 m wide to $>200 \mathrm{~m}$ (Figure 7). Thin, discontinuous fine-grained partings are commonly observed separating NC elements, especially lower in the formation. SF elements up to $2 \mathrm{~m}$ in thickness are common at the bases of sandstone storeys, but may be found throughout the interval.

LA and DA elements are rare in the lower two-thirds of the formation, but increase in abundance in the upper one-third (Figure 7). Where observed, accretionary elements are typically between 2-6 $\mathrm{m}$ in thickness and have a distinctive wedge-shaped geometry bounded by 4th order surfaces with internal 3rd order surfaces.

In some instances Facies A2 is associated with the finer-grained facies of Association B. These occur as CS elements. CS elements are typically observed as lenticular bodies, although one CS element is observed as a clear channel feature with "wings" extending out on either side (Figure 7). This element has a maximum channel fill of $1.6 \mathrm{~m}$ and is $\sim 35 \mathrm{~m}$ wide not including the wings. At the margins, this CS element becomes increasingly interbedded with ripple cross-laminated sandstone and siltstone.

Sedimentary structures within Facies A2 are dominantly trough cross-bedding in sets up to $2.0 \mathrm{~m}$ thick, commonly $<0.5 \mathrm{~m}$ (Figure 8 ). Trough cross-beds are gently curved in both flow-parallel and transverse sections and at times appear planar. Trough cross-beds are typically lined with gravel, locally display rhythmic grain-size alternations and are preserved as a complex mosaic of troughs rather than as coherent cosets. Crossbed set thickness usually decreases upward through
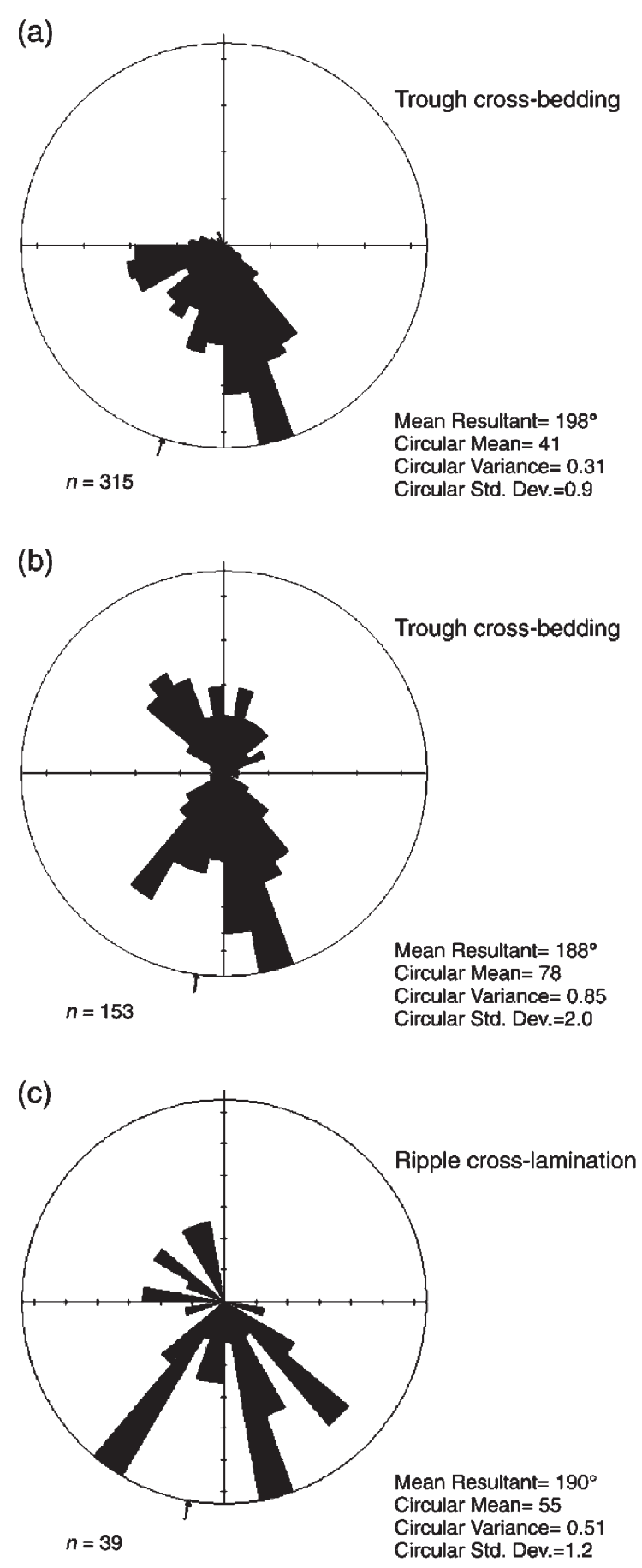

Figure 9. Rose diagrams summarizing paleocurrent data collected from current generated structures within the Betts Creek Beds from (a) Facies A2, (b) Facies A3, (c) Facies B3.

sandstone bodies. In several areas, convex-up cross-bedding ('humpback' cross-bedding; cf. Saunderson and Lockett, 1983) is observed in which topset, foreset, and bottom set beds are all preserved. 
Table 3. Calculated values for mean dune height $\left(h_{\mathrm{m}}\right)$ and mean channel bankfull depth $(d)$ using mean thickness of cross-sets $\left(s_{\mathrm{m}}\right)$ using the methodology of Bridge and Tye (2000)

\begin{tabular}{lllll}
\hline & $\begin{array}{l}\text { Mean } \\
\text { Cross-set } \\
\text { Thickness } \\
\left(s_{\mathrm{m}}\right)\end{array}$ & $\begin{array}{l}\text { Standard deviation } \\
\left(s_{\mathrm{sd}}\right)\end{array}$ & $\begin{array}{l}\text { Mean } \\
\text { dune } \\
\text { height } \\
\left(h_{\mathrm{m}}\right)\end{array}$ & $\begin{array}{l}\text { Estimated } \\
\text { water } \\
\text { depth } \\
(d)\end{array}$ \\
\hline Facies A2 $(n=315)$ & $0.40 \mathrm{~m}$ & $0.29 \mathrm{~m}$ & $1.18 \mathrm{~m}$ & $7.06-11.76 \mathrm{~m}$ \\
Facies A3 $(n=153)$ & $0.43 \mathrm{~m}$ & $0.25 \mathrm{~m}$ & $1.25 \mathrm{~m}$ & $7.51-12.52 \mathrm{~m}$ \\
\hline
\end{tabular}

In addition to trough cross-bedding, diffuse, flat lamination is common in the lowermost storeys. Discontinuous siltstone partings are common throughout Facies A2. Partings are typically $<2 \mathrm{~cm}$ and are of limited lateral extent. In some instances, partings preserve plant material referable to Glossopteris sp., Vertebraria, and Cordaites sp.

Soft-sediment deformation (loading and convolute bedding) is commonly associated with the basal contacts described above. Horizons of soft-sediment deformation may be traced laterally over $<100 \mathrm{~m}$ 's, but these horizons normally vary in both vertical extent and degree of deformation. Cross-beds are also observed to pass laterally into convolute bedding in several places.

Paleocurrent directions measured from trough crossbeds are predominantly southward (mean $=198^{\circ}$; Figure 9a), with little dispersion about the mean.

5.1.2.1. Interpretation - The sheet-like external and internal geometry, overall low dispersion of paleocurrent directions, dominantly coarse-grained sediments, rare evidence of systematic lateral accretion (especially in the lower portion of the formation), and the erosionally based, channelized nature of Facies A2 all indicate deposition within low-sinuosity, most likely braided, alluvial channels (cf. Bridge, 1985; Bristow and Best, 1993). On the basis of external and internal geometry of Facies A2, channels were up to $8 \mathrm{~m}$ deep, but typically 3-5 m, and sediment accumulated by the lateral switching of channels across a broad channel belt. The thickness of individual NC elements is not considered to be representative of channel depth, due to the nature of erosional surfaces separating NC elements. It is suggested that the preserved sandstone bodies are remnants of larger channel sandstones (cf. Martinsen et al., 1999). An estimation of channel depth, however, may be ascertained from cross-bed thickness. A number of experimental studies have related the set thickness of cross-strata and dune height to the relationship between dune height and water depth (Leclair et al., 1997; Bridge, 1997; Leclair and
Bridge, 2001) and these have been applied to both modern and ancient sediments (Bridge and Tye, 2000; Leclair and Bridge, 2001; Adams and Battacharya, 2005). In order to calculate mean bedform height $\left(h_{\mathrm{m}}\right)$, cross-sets are measured and a mean $\left(\mathrm{s}_{\mathrm{m}}\right)$ and standard deviation $\left(\mathrm{s}_{\mathrm{sd}}\right)$ are calculated. If the $s_{\mathrm{sd}} / s_{\mathrm{m}}$ ratio is $\sim 0.88( \pm 0.3)$ mean dune height can be estimated (Leclair and Bridge, 2001) as:

$$
\begin{gathered}
\beta \cong s_{\mathrm{m}} / 1.8 \\
h_{\mathrm{m}}=5.3 \beta+0.001 \beta^{2}
\end{gathered}
$$

The relationship between dune height and channel depth (d) shows a wide range of values that range from $3<d / h_{\mathrm{m}}<20$ (Bridge and Tye, 2000), however it appears that $d / h_{\mathrm{m}}$ values average between 6 and 10 (Allen, 1982; Bridge and Tye, 2000).

Table 3 shows the estimated bankfull flow depth for the $B C B$, which ranges from 7.1-11.8 $\mathrm{m}$. These values are in general agreement with observations from erosional relief observed along channel margins and from bar accretionary units that can also be used to estimate channel flow depth (Bridge, 2003). Overall, the channel systems within the BCB can be interpreted through paleocurrents, architectural features, and quantitative estimates as being $>400 \mathrm{~m}$ wide and $\sim 7-12$ m deep.

Channels had considerable erosional capability that is indicated by the excision of underlying strata. The nested character of the channels (abundance of NC elements) suggests that they were repeatedly eroded and filled, and flood-plain sediments were largely removed (cf. Reinfelds and Nanson, 1993). The dominance of sandstone-filled channels and lack of fine-grained channel fills are consistent with a braided river interpretation (Bridge, 1985). The fine-grained partings that separate some storeys and occur as discontinuous lenses throughout Facies A2 are interpreted as remnants of the slack-water bar-top component of intra- or interchannel islands or small floodplain deposits (cf. Reinfelds and Nanson, 1993) in a multi-channel system. Small-scale channels incised into the upper contacts of sandstone bodies are interpreted as cross-bar channels.

The dominance of trough cross-bedding and the rarity of evidence for systematic lateral accretion within this facies, especially within the lower part of the formation, suggest that channel floors were relatively devoid of macroforms, and instead were covered by moderately-sized dunes that migrated in a predominantly downstream direction. Considering the complexity of trough cross-bedding preserved as mosaics rather than coherent cosets, the dunes were most likely low-relief, three-dimensional, slightly sin- 
uous dunes. Paleocurrent data also suggest that dune migration had a minor across-channel migration component. Lateral accretion is observed within the upper part of the formation and records lateral accretion on braid bars in these areas. The general paucity of lateral accretion in the lower part of the formation compared to the upper part suggests that braiding became more pronounced during the history of the Betts Creek alluvial system.

The convex-up crossbedding ('humpback' dunes) is similar to structures produced experimentally (Simons et al., 1965; Saunderson and Lockett, 1983) and found within ancient sequences (Allen, 1983; Røe, 1987; Røe and Hermansen, 1993; Fielding and Webb, 1996; Hjellbakk, 1997). In each of these cases, these structures were representative of the transition from dune to upper-stage, plane-bed flow regimes. The abundance of chaotic and convolute bedding is interpreted as autokinetic (produced purely by sedimentary processes; sensu Leeder, 1987) in origin and suggests rapid sediment accumulation rates (Allen, 1982; Owen, 1996; Røe and Hermansen, 2006). Rapid sediment accumulation rates are further supported by the occurrence of SF elements found at the bases of sandstone storeys. Where SF elements are preserved, they are interpreted as channel-lag deposits that were transported within the thalweg of major channels. The coarse nature of the lag deposited within SF elements indicates that flows were at times powerful.

Where this facies is associated with Association B as CS elements, it is interpreted as most likely representing crevasse splays.

\subsubsection{Facies A3 - bidirectional trough cross-bedded sandstone}

Facies A3 is similar to Facies A2 in overall character; however, key differences warrant a separate facies designation. Facies A3 occurs in sandstone bodies 1-2 m in thickness with overall sheet-like geometries. Lower and upper contacts are commonly sharp, but locally lower contacts may be gradational. Facies A3 everywhere overlies Faces A2. Locally, upper bedding plane contacts preserve symmetrical wave ripples (Figure $6 \mathrm{~d}$ ) trending $016^{\circ}$, and Thalassinoides and Planolites burrows. In some areas, upper contacts are also associated with small-scale channels of Facies B1 and B3.

Internally, sandstone bodies of Facies A3 are composed of NC elements with very similar geometries to the NC elements found in Facies A2. Trough cross-bedding is the dominant sedimentary structure, although small-scale trough cross-bedding, flat lamination, ripple cross-lamination, and local parting lineation and carbonaceous/coaly laminae are common near the upper $(\sim 1 \mathrm{~m})$ bed contacts with either overlying sandstone storeys of this facies or fine-grained sediments of Facies B1-3.

Paleocurrent data from trough cross-bedding show a bidirectional distribution with an overall southward direction (mean $=188^{\circ}$; Figure $9 \mathrm{~b}$ ) and in some instances bipolar distributions (herringbone cross-stratification; Figure 6e, f).

5.1.3.1. Interpretation - Facies A3 is interpreted as the deposits of tidally influenced alluvial channels. The overall similarities and close association with Facies A2 suggest that Facies A3 was deposited under similar conditions. Channel depth estimates within this facies are 7-12 m, similar to those from Facies A2 (Table 3).

Paleocurrent distributions, along with the presence of herringbone cross-stratification, suggest that the upper storeys of sandstone beds have been strongly influenced by reversing flows, most likely related to tidal processes. Tidal processes have been documented to occur 0-300 km inland from a coeval shoreline in modern environments (Gelfenbaum, 1983; Allen, 1991). However, in this case the increasing mud component, ripple crosslamination, wave ripples, and marine trace fossils (i.e. Thalassinoides) suggest deposition in near-coastal environments. The association with small channel fills of an estuarine character (Facies B3, see below) is consistent with such an interpretation.

\subsubsection{Facies A4 - interbedded sandstone and siltstone}

Facies A4 is composed of interbedded sandstone and siltstone in varying proportions, in units up to $3 \mathrm{~m}$ thick. This facies is preserved as CF elements and occurs predominantly in the upper half of the formation. Lower contacts are sharp and erosional, and always occur above sediments of Facies A2. Upper contacts are erosional, sharp, undulatory, and generally concave-upward boundaries with overlying Facies A2 sediments. Although sedimentary structures are not observable in detail due to inaccessibility, structures representing low-energy conditions from waning flows such as ripple cross-lamination and interlamination structures (flaser, wavy, lenticular, pinstripe bedding) are thought to dominate within this facies.

Sandstone beds are $<1 \mathrm{~m}$ in thickness, exhibiting lateral variability with beds $<10 \mathrm{~m}$ in length. Sandstone to siltstone proportion decreases upwards.

5.1.4.1. Interpretation - The occurrence of Facies A4 above Facies A2 and its limitation to CF elements suggest that these sediments were formed during abandonment of river channels. This facies, therefore, represents the abandonment fill of the low-sinuosity alluvial channel deposits of Facies A2. Facies A4 is everywhere overlain by Facies A2, suggesting that abandoned channels 

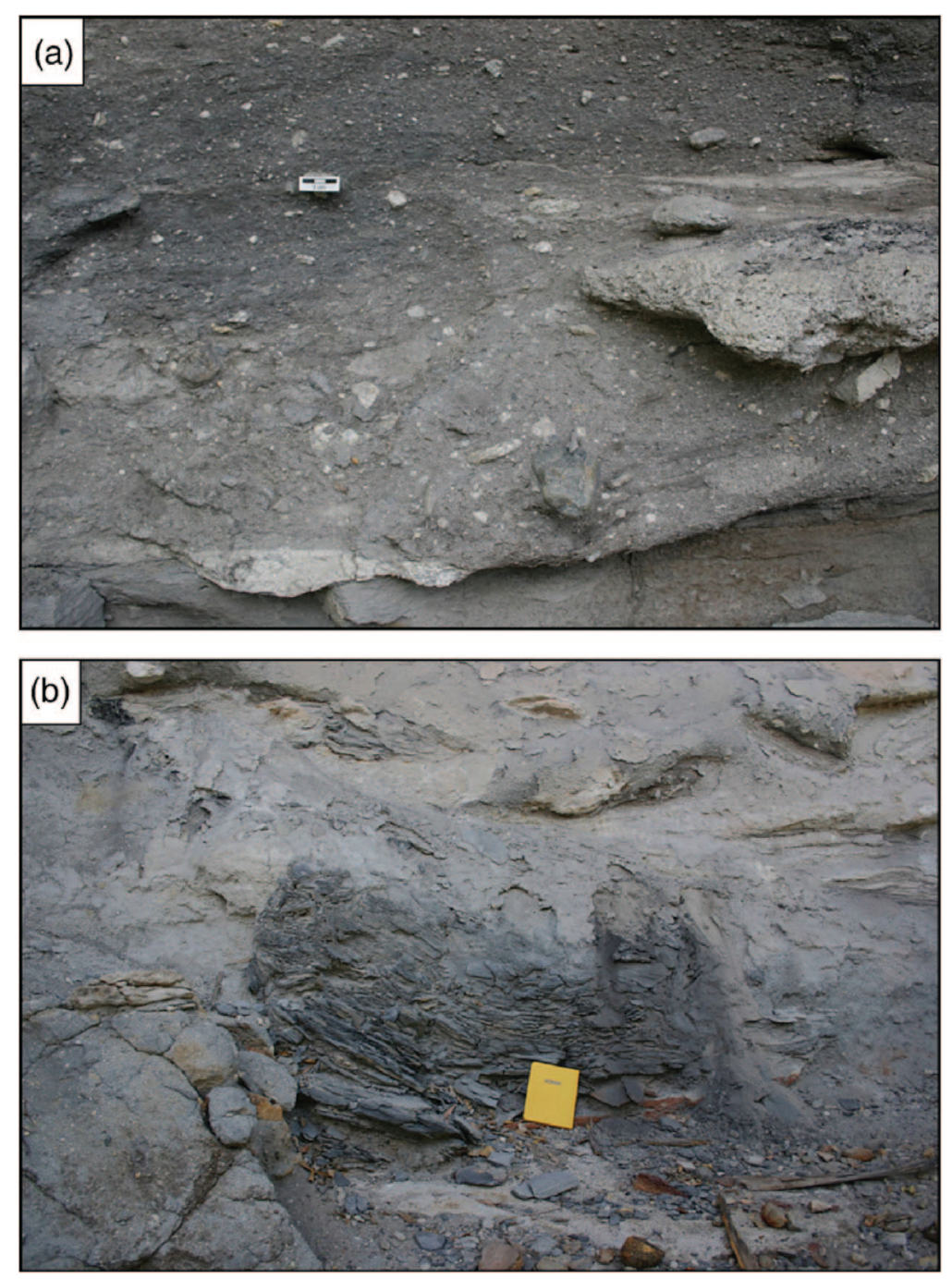

Figure 10. Facies A5. (a) Overall characteristic fabric of Facies A5 showing clast-rich nature (Section 12$)$. (b) Large ( 1.7 m) siltstone raft within the lower portion of this facies. Note the irregular outline of the clast and that the siltstone still preserves internal lamination. Notebook $=20 \mathrm{~cm}$.

within the floodplain were reactivated by subsequent channels (cf. Reinfelds and Nanson, 1993). This further supports the interpretation that sediments of A2 accumulated by lateral switching of active channels across a broad channel belt.

\subsubsection{Facies A5 - diamictite}

Facies A5 is a distinctive, light gray, clast-rich (10$25 \%$ clasts), sandy diamictite (Figure 10a; c.f. Moncrieff, 1989). Clasts range from granules to boulders, $<1.7 \mathrm{~m}$ in length. Clasts are basement (granite, gneiss, quartz), first-cycle volcanic tephra, and intraformational siltstone and sandstone. Intraformational clasts are irregular and typically preserve internal bedding (small-scale trough cross-bedding, ripple cross-lami- nation, flat lamination) and soft-sediment deformation (Figure 10b). Clasts are poorly sorted and matrix-supported. Facies A5 is typically unstratified, but crude bedding and clast imbrication (indicating flow to the southeast) have been observed at Section 19 (see Figure 3 for location). Wispy silt laminae, coaly traces, and macerated plant material are common in the upper part of this facies.

Facies A5 is rare, laterally discontinuous, and occurs exclusively within CF elements that may extend for several hundred meters. The maximum thickness of Facies A5 at outcrop is $3 \mathrm{~m}$. It commonly overlies Facies B1 and basal contacts are sharp and undulatory. Upper contacts are sharply defined by the overlying Facies A2 or locally by Facies B1. 

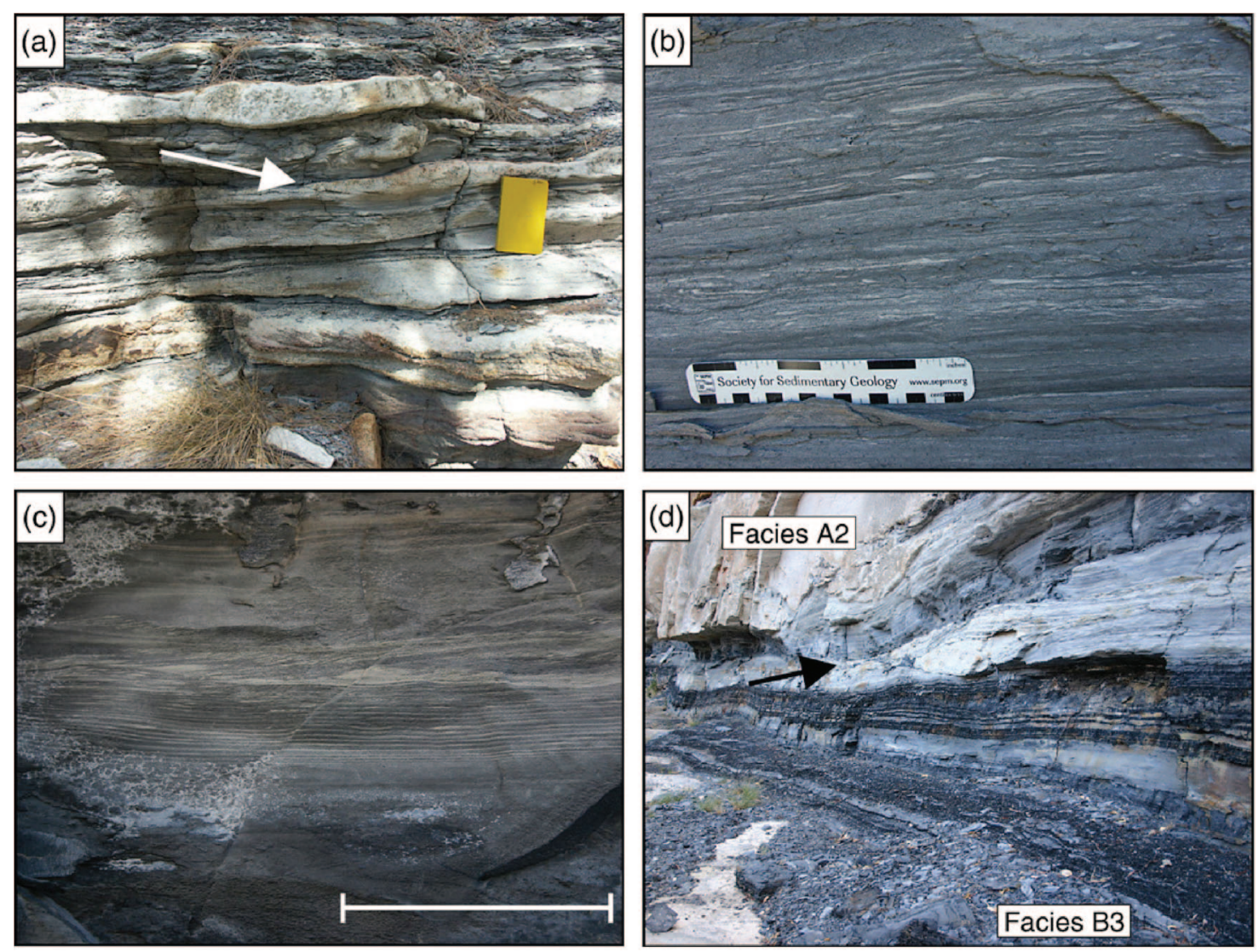

Figure 11. Facies B1 and B2. (a) View of "proximal" Facies B1 at Section 10. Note the loading associated with the basal contacts of sandstone beds. Some sandstone beds pinch out laterally (arrow). Notebook $=20 \mathrm{~cm}$. (b) View of “distal” Facies B1. Scale = $15 \mathrm{~cm}$. (c) Facies B1 at Section 13 displaying rhythmic alternations of fine-grained sandstone and siltstone. Scale bar $=50 \mathrm{~cm}$. (d) View of Faces B2 at Section 13 showing the abrupt contact with overlying Facies A2. Note the small channel form incised and filled with Facies B1 (arrowed). Section is oblique to paleoflow. Section approximately $8 \mathrm{~m}$.

5.1.5.1. Interpretation - Facies A5 is interpreted as reworked pyroclastic material deposited by debris flows. The extremely poor sorting, lack of internal stratification, and presence of matrix-supported clasts are all characteristic of subaerial debris flows documented from both ancient and modern environments, where deposition is en masse rather than by grain-by-grain sedimentation (Nemec and Steel, 1984; Smith, 1986; Smith and Lowe, 1991; Major, 1997). Intraformational clasts with irregular shapes and displaying internal stratification suggest that debris flows were relatively viscous and lacked turbulence (cf. Jorgensen and Fielding, 1999; Kataoka and Nakajo, 2002) in order for these features to be preserved during transport and deposition.

It is believed that debris flows formed in association with contemporaneous volcanism, with source area(s) to the north and/or east. During this time interval widespread volcanic activity was occurring on the northeastern margin of the Bowen Basin as a result of foreland tectonics and the establishment of a continental volca- nic arc (Fielding et al., 2001), and may have provided the volcaniclastic detritus that sourced debris flows. Paleocurrent data from the Bowen Basin show that during the Late Permian (263-258 Ma) alluvial conditions were established that led to an overfilling situation in which first-cycle volcanic detritus spilled across the Springsure Shelf into the Galilee Basin (Fielding et al., 2001). The absence of coeval primary proximal volcaniclastic facies associated with Facies A5 suggests that the location of volcanism was far away and most likely extrabasinal, which is consistent with an interpretation that volcanism in the Bowen Basin sourced debris flows. While debris flows generated on alluvial fans rarely extend further than $10 \mathrm{~km}$, volcanic debris flows can travel $>100 \mathrm{~km}$ away from the source (Smith, 1986; Mothes et al., 1998). Facies A5, therefore, records evidence for distal debris-flow deposition as the result of large-scale volcanism several hundred kilometers away. The paucity of airfall tuff beds within the study area is noteworthy. Although no coeval primary volcaniclastic sed- 

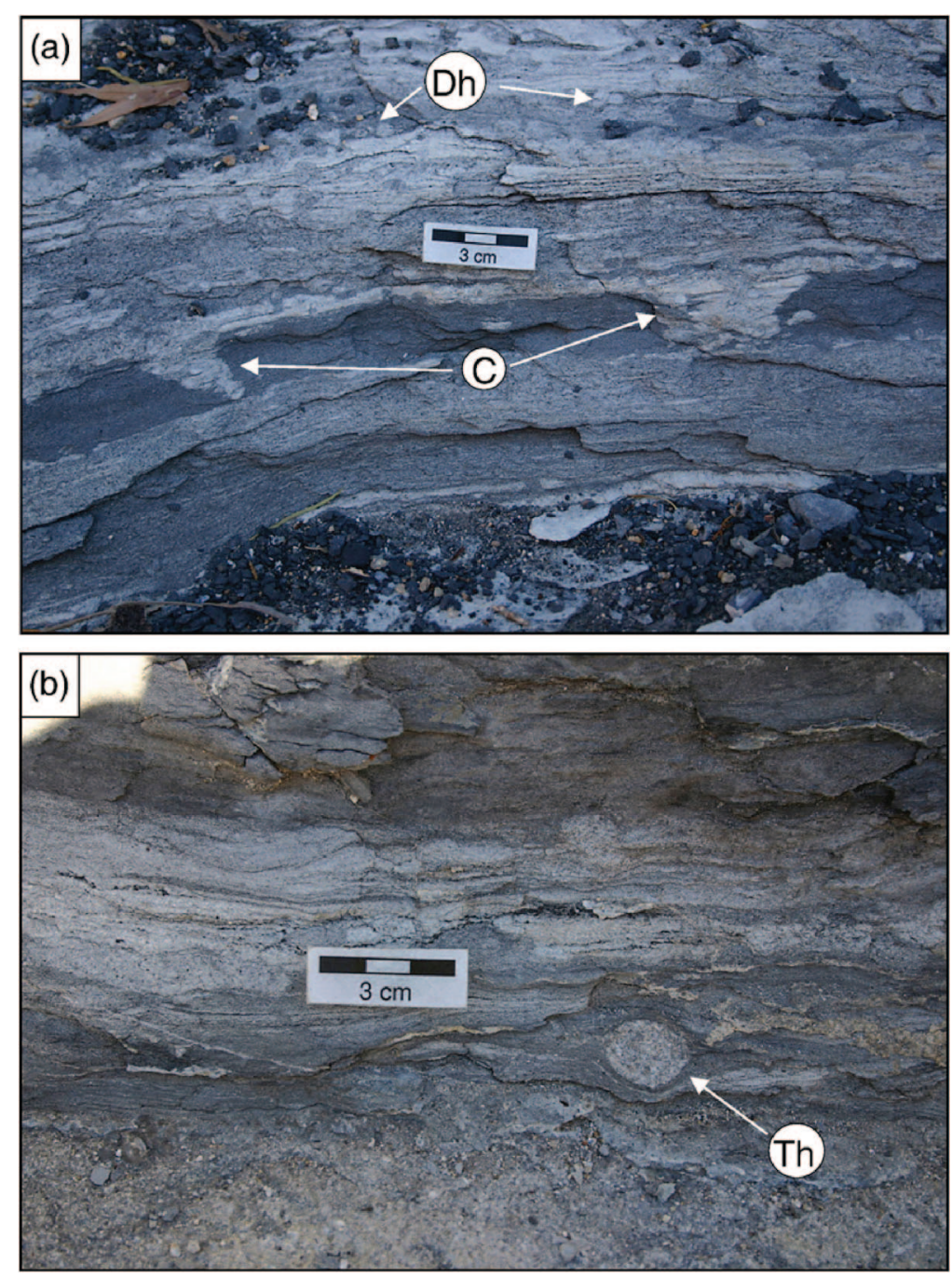

Figure 12. Facies B3. (a) Photograph is oblique to bedding showing the overall bioturbated fabric within Facies B3 (BI = 4-5). Diplocraterion habichi $(\mathrm{Dh})$ is preserved on bedding surfaces, while Conichnus $(\mathrm{C})$ traces are preserved on a vertical section. (b) Cross-sectional view of Thalassinoides (Th) burrow.

iments occur within the northeastern Galilee Basin, explosive volcanism was ongoing during the Late Permian in the Bowen Basin. Airfall from such explosive volcanism could reach the study area, but recent climate models predict westerly trade winds (offshore) during the Permian winter and southerly directed winds during summer (Gibbs et al., 2002). Under these circumstances, airfall from volcanism would not be expected in the northeastern portion of the Galilee, because prevailing surface winds were blowing in the opposite direction.

All BCB debris-flow deposits are confined to CF elements that have sharp, concave-up, channelized bases. These debris flows probably exploited pre-existing topography by occupying existing channels. Debris flows within volcanic settings have been shown to follow drainage paths and be partially or completely confined to channels (Pierson and Scott, 1985). The intraformational siltstone and sandstone clasts in the $\mathrm{BCB}$ are most likely the result of floodbasin and channel sediment entrainment during the occupation of channels by debris flows. Further support for this interpretation lies in the characteristics of Facies A5 at Section 19, where clast imbrication and crude bedding appear. Imbrication is consistent with a debris-flow interpretation (Smith, 1986), in which particles at the base of debris flows display a directional fabric formed by pulsed shearing within the flow body (Mulder and Alexander, 2001). The direction of imbrication predominantly to the southeast is comparable to the overall paleoflow measured from fa- 


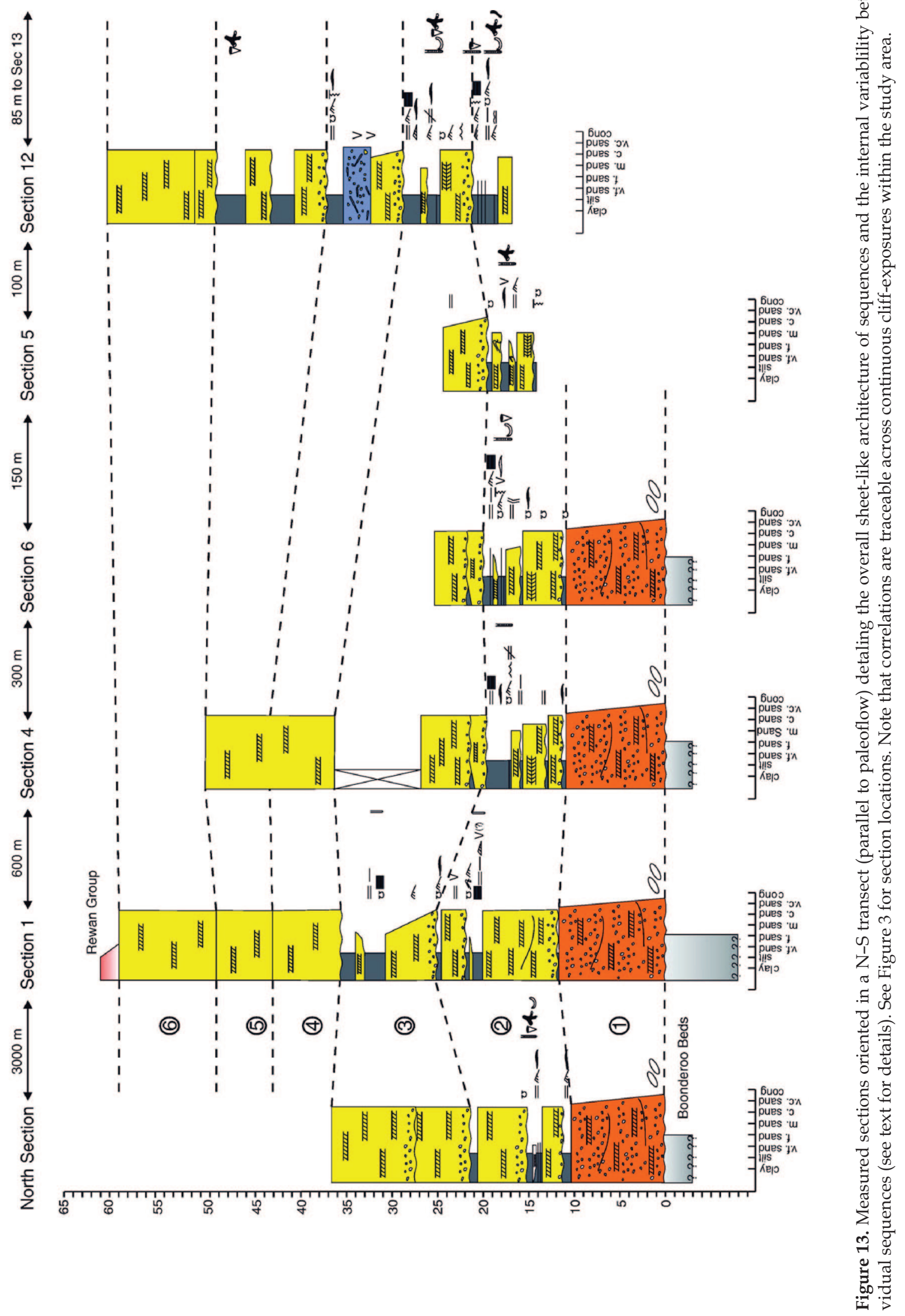




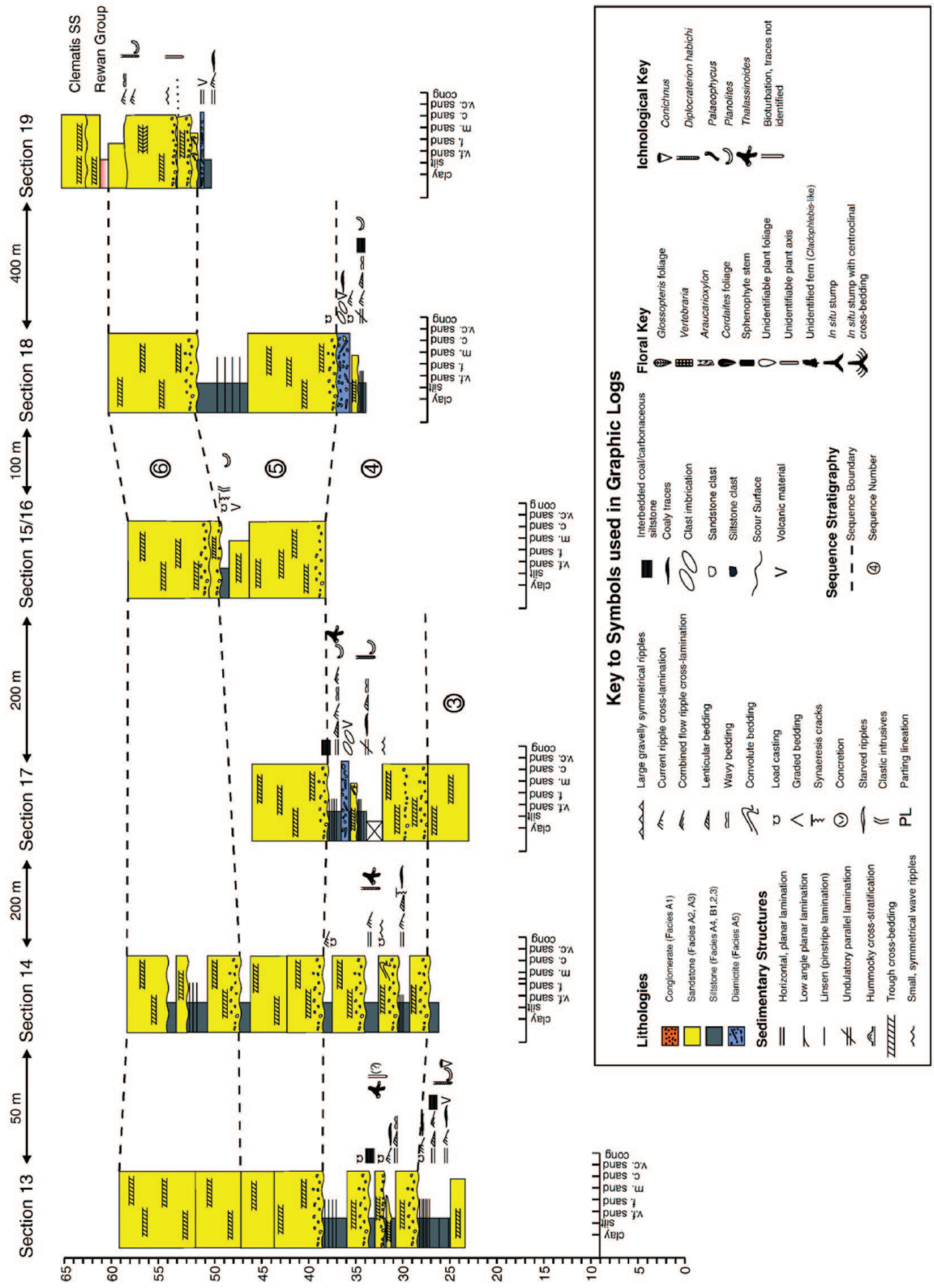

בิ 
cies within the channel association, suggesting flow was confined by pre-existing topography.

\subsection{Facies Association B - floodbasin deposits}

\subsubsection{Facies B1 - interbedded to interlaminated sandstone and siltstone}

Facies B1 comprises intervals up to $6 \mathrm{~m}$ thick of interbedded to interlaminated sandstone and siltstone. The interbedded/interlaminated nature and the proportion of sandstone to siltstone within this facies vary markedly depending on where in the formation it is found (laterally and vertically) and the relationships to other facies. As a result, this facies is typically a complex mosaic of sandstone and siltstone that varies laterally and vertically. Two "endmembers" ("proximal" and "distal") are described below in order to give an adequate description of the range of characteristics found within Facies B1. In general, sandstone beds are medium- to fine-grained and have sharp, basal and upper contacts. Siltstones are medium to dark gray and are characterized by a number of interlamination structures including pinstripe (linsen), lenticular, and wavy lamination. Siltstones also contain significant amounts of tuffaceous material.

The "proximal" endmember (Figure 11a) is recognized where Facies B1 is connected to channel margins of Facies A2. Here this facies consists of interbedded, fining-upwards 70:30 to 50:50 sandstone:siltstone,. Sandstones range from medium to very fine, but are mostly medium-grained. Individual beds are typically 2-10 cm thick. Both upper and lower bed contacts are sharp and undulatory, and lower contacts show varying amounts of soft-sediment deformation mainly in the form of loading and localized convolute bedding (Figure 11a). Many individual sandstone beds are laterally persistent, but some have been observed as lensoid bodies $<5 \mathrm{~m}$ wide. Sandstones contain small-scale cross-stratification and ripple cross-lamination. Siltstone beds are $1-5 \mathrm{~cm}$ thick and contain mainly pinstripe and lenticular bedding, as well as abundant ripple crosslamination (locally occurring as climbing ripples). No trace fossils have been observed within the proximal endmember.

Where associated with channel sandstones of Facies A2, the thickly interbedded nature of Facies B1 is restricted laterally, and with increasing distance from the channel margin, sand percentage and grain-size decrease and the unit as a whole passes and interfingers into thinly interbedded and increasingly more interlaminated sandstones and siltstones of the more "distal" endmember (Figure 11b). This lateral change occurs over a few tens of meters. In several locations the proximal variant of Facies B1 occurs within LE elements with inclined accretionary layers dipping $\sim 5-10^{\circ}$ at the margins of channel bodies (Figure 7).

Siltstones of the distal endmember of Facies B1 contain the same features as mentioned above but additionally show abundant coaly laminae, rare Planolites, and starved ripples. These siltstones also preserve fragments of Glossopteris, Vertebraria, and Cordaites. This endmember of facies B1 occurs within OF lithosomes and is laterally persistent over several hundred meters.

Additionally, Facies B1 appears locally as medium to dark gray massive to fissile siltstone with an increasingupward organic content. Plant remains of Glossopteris, Vertebraria, Cordaites, and other unidentifiable plant fragments are common on bedding planes. This variant of Facies B1 is commonly found as partings within or separating sandstone beds of Facies A2 and A3, and typically passes vertically into Facies B2.

At one locality, Facies B1 displays rhythmic laminations of heterolithic fine-grained sand and silt (Figure 11c).

5.2.1.1. Interpretation - Facies B1 is interpreted as floodbasin deposits that range from environments proximal to channel margins to distal locations not influenced by active channel processes. The "proximal" endmember of Facies B1, occurring laterally adjacent to channel margins and composed of interbedded sandstone and siltstone, represents a proximal floodbasin setting, with sediment deposited by initially high energy sheet flows from waning flood currents. These conditions produced the sharply bounded nature of sandstone bodies, and then as flow energy decreased, low-energy currents and suspension fallout sedimentation occurred. Where this facies occurs as LE elements, it is interpreted as levee deposits as the geometry is similar to other examples (cf. Fielding et al., 1993; Michaelson et al., 2000; Ray and Chakraborty, 2002). Depositional dips in Facies B1, representing the alluvial-ridge topography, the lateral fining into more distal floodbasin deposits, and close association with channel margins, are all consistent with a proximal overbank/levee interpretation (cf. Fielding et al., 1993).

Thicker and more laterally extensive sandstone beds within Facies B1 are similar to splay deposits (cf. Farrell, 1987; Tye and Coleman, 1989; Jorgensen and Fielding, 1996), and most likely represent the proximal portions of crevasse splays. However, for the most part, sandstone beds are not laterally persistent, and crevassing is not thought to have been a major process.

The "distal" endmember of Facies B1, due to its lateral and vertical relationships, suggests processes similar to those of the "proximal" end member. The paucity of sandstone beds and abundance of interlamination 
structures representative of a lower flow regime suggest that sedimentation was primarily due to suspension fallout. In these cases, Facies B1 was not affected by active channel processes but deposition occurred mainly during sheet-flood events in shallow ponds. The rarity of trace fossils suggests that these ponds were anoxic or dysoxic. Here, and where associated with Facies B2, Facies B1 represents a transitional environment from shallow, stagnant ponds, to peat-forming mires where abundant plant material and coaly laminae occur.

At one locality, Facies B1 shows evidence of influence from tidal processes. The deposits of fine-grained sandstone and siltstone in rhythmic alternations are interpreted as tidal rhythmites (Figure 11c).

\subsubsection{Facies B2 - carbonaceous siltstone/coal}

Facies B2 is composed of laterally extensive carbonaceous siltstone and coal in units up to $2.5 \mathrm{~m}$ thick in the study area, but reaching up to $10 \mathrm{~m}$ thick in cored sections (GSQ Hughenden 3-4R). Basal contacts are gradational from Facies B1, whereas upper boundaries are sharp and erosionally truncated by Facies A2 (Figure 11d). At the lower contacts, Facies B2 is variably interbedded with Facies B1. Where well-developed, this facies becomes increasingly coal-rich upward. This facies displays lateral continuity over several kilometers in extensive OF lithosomes. Abundant plant remains are preserved at several horizons, including Glossopteris, Vertebraria, Araucarioxylon-like wood, and Cordaites. In situ tree stumps up to $20 \mathrm{~cm}$ wide are preserved at the top of Facies B2 in one area. Stumps are rooted into a carbonaceous horizon that also contains well-preserved Glossopteris foliage, and are buried by sediments of Facies B1 displaying centroclinal cross-stratification.

In several places, sharply bounded sandstone bodies of Facies A2 up to $2.5 \mathrm{~m}$ thick occur within this facies.

5.2.2.1. Interpretation - Facies B2 is the result of peat accumulation in coastal wetland environments. Peat accumulation was evidently in situ from the abundance of roots (Vertebraria). The number of channelized sandstone bodies (Facies A2) within this facies suggests that the wetland may have been crossed by a network of small channels. The extensive sheetlike geometry of Facies B2 suggests that the mires were predominantly low-lying, rheotrophic environments, rather than raised and rain-water fed swamps (McCabe, 1984). The association of Facies B2 with Facies B3 (see below) suggests that these were coastal wetland environments situated on a coastal plain near estuarine embayments.
5.2.3. Facies B3 - bioturbated interbedded sandstone and siltstone

Facies B3 comprises intervals of bioturbated interbedded very fine- to fine-grained sandstone and siltstone no more than $50 \mathrm{~cm}$ and in most places $<10 \mathrm{~cm}$ thick. Medium, gray, sandy siltstone is the predominant lithology within this facies with siltstone:sandstone proportions varying from 50:50 to 90:10 depending on location. Lower contacts are typically sharp. Facies B3 is everywhere observed overlying sediments of Facies A3. Upper contacts are commonly gradational into Facies B1, but are locally sharply bounded by Facies B1 and B2. This facies occurs at several stratigraphic horizons and can be traced laterally over at least $3 \mathrm{~km}$ within $\mathrm{OF}$ lithosomes.

Sandstone beds are sharply bounded and some are discontinuous, passing laterally into sandy siltstone. Sandstones are $<3 \mathrm{~cm}$ in thickness and commonly ripple cross-laminated (current-, wave-, and combined flow-generated). Siltstones are characterized by a variety of interlamination structures ranging from pinstripe (linsen) to lenticular and wavy lamination, and thicker beds are internally flat or ripple cross-laminated. Measurements from ripple cross-lamination indicate paleoflow to the southwest (mean resultant $=190^{\circ}$; Figure 9c), although azimuths range from northwest to southeast. Small synaeresis cracks are common throughout this facies, and other soft-sediment deformation structures occur locally. At one location (Section 6) clastic dikes composed of very fine- to fine-grained sandstone were observed at the lower contact of this facies with underlying Facies A3. Sandstone dikes are variable in width ranging from $10-20 \mathrm{~cm}$ and up to $50 \mathrm{~cm}$ in length. No preferred orientation was observed.

The intensity of bioturbation is variable throughout Facies B3, but typically decreases upwards. Bioturbation varies from location to location and within individual beds. The Bioturbation Index (BI, Bann et al., 2004: where BI $=0$ is no bioturbation and BI $=6$ represents complete bioturbation) ranges from 0 to 5 . The trace fossil suite is low in diversity and dominated by Diplocraterion habichi (Figure 12a), Conichnus (Figure 12a), and Thalassinoides (Figure 12b), with minor Planolites and Palaeophycus sp. D. habichi are most often observed in plan view as small $(1-5 \mathrm{~mm})$ paired vertical burrows. The other traces were readily identified in both plan and cross-sectional views. The trace fossils have reduced sizes, except in a few instances where especially large individuals $(<15 \mathrm{~cm})$ of Conichnus were noted. Trace fossils occur throughout Facies B3 and do not show any preferential clustering at any one stratigraphic horizon. 


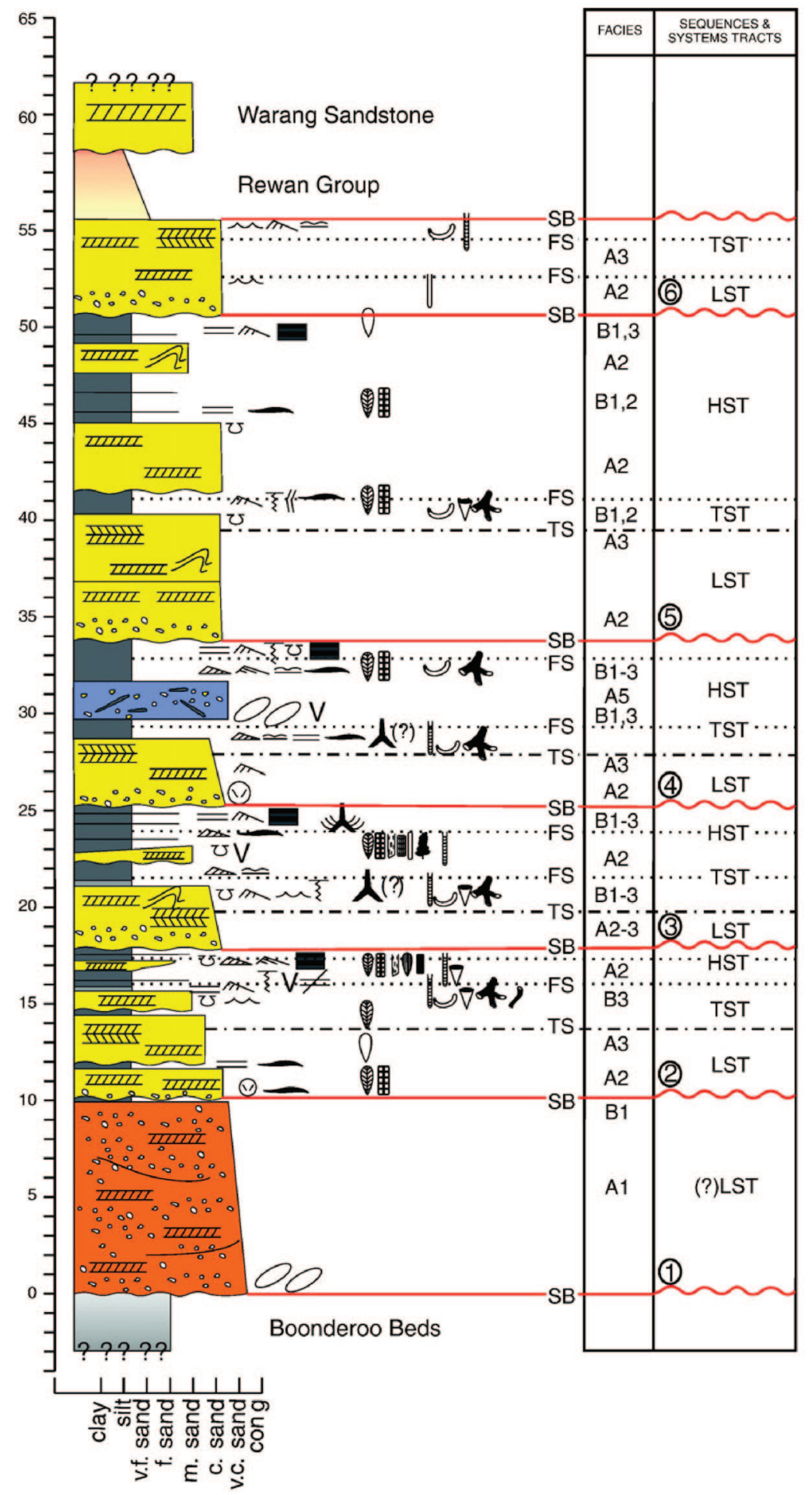

Figure 14. Composite measured section of the Betts Creek Beds detailing vertical facies variations and sequence stratigraphic interpretations. Key as in Figure 13.

Small-scale channel forms $(2 \times 20 \mathrm{~m})$ were observed in several areas incised into sediments of Facies A2, A3, B1, B3 and infilled by Facies B3.
5.2.3.1. Interpretation - Facies B3 was deposited within estuaries or coastal embayments. The dominance of ripples (wave-and tide-influenced) and wavy and 
lenticular bedding implies deposition within a shallowwater environment. Bipolar and bimodal paleocurrent distributions also reflect tidal processes.

Synaeresis cracks suggest deposition in a permanently subaqueous, brackish-water setting. Cracks found throughout Facies B3 have been interpreted as the product of synaeresis rather than desiccation due to the lack of well developed polygonal patterns on bedding planes, elongate to trilete planform, ptygmatically folded cross-section, and the absence of other evidence that would suggest subaerial exposure (soil development, roots, etc.). Synaeresis cracks form in response to tension as muddy, water-saturated sediment loses water to an overlying fluid layer causing an increase in the strength of interparticle forces within the clays (cf. Plummer and Gostin, 1981; Allen, 1982). They typically form in muddy environments where there are large fluctuations in salinity (Burst, 1965). Salinity variations during or immediately following the deposition of muddy sediments induced the formation of synaeresis cracks in experiments (Plummer and Gostin, 1981; Allen, 1982). The appearance of synaeresis cracks in association with sandstone beds in Facies B3 suggests that sand deposition was accompanied by an influx of saline water.

The trace fossil assemblage is also consistent with a brackish-water interpretation because it contains a mixture of size-reduced, simple dwelling and feeding structures (deposit-feeders dominant, with less abundant suspension feeders) characteristic of opportunistic suites. It is a restricted expression of a mixed Skolithos/ Cruziana Ichnofacies that is characteristic of inshore coastal environments (cf. Bann et al., 2004). Typical estuarine trace fossil assemblages from both modern and ancient settings are characterized by (1) low diversity, (2) ichnotaxa typically found in marine environments, (3) reduced size compared to open marine counterparts, (4) simple burrows constructed by trophic generalists, and (5) vertical and horizontal burrows common to both Skolithos and Cruziana Ichnofacies (Howard and Frey, 1973; Ekdale et al., 1984; Beynon and Pemberton, 1992; Pemberton et al., 1992; Bann and Fielding, 2004; Bann et al., 2004). These criteria can all be recognized within Facies B3. The preponderance of diminutive traces found within Facies B3 is considered to be an adaptive response to salinity-induced physical and chemical stresses. Size reduction is most noticeable in organisms that maintain constant contact with surficial brackish waters, whereas deeper, deposit-feeding structures display less size reduction (Bann and Fielding, 2001). Larger forms of Conichnus are believed to represent sites at a distance from the brackish water interface.
The combined sedimentological and ichnological data, therefore, point to a highly stressed brackish water environment (i.e. coastal/estuarine embayment) that was influenced by both wave and tidal processes.

\section{Stratigraphic and sequence architecture}

One of the most distinctive features in the vertical stacking patterns of the Betts Creek Beds is a series of 6 unconformity-bounded cycles each 10-14 m thick (Figure 13). These cycles could represent autogenic cycles, highfrequency parasequences (Van Wagoner et al., 1988; Naish and Kamp, 1997), or true sequences formed in lowaccommodation settings (Kidwell, 1997; Fielding et al., 2000; Bann et al., 2004). Given that the BCB represent the entire Late Permian Galilee Basin fill ( 20 myr), it is likely that these cycles represent true sequences. The $\mathrm{BCB}$ display the typical sequence architecture characteristic of the examples cited above that were preserved in low-accommodation settings where they are thin, condensed, and show considerable top truncation of the highstand systems tract.

Although autogenic cycles may result in regular sedimentary cycles, it is unlikely that semirandom processes such as river avulsion and mire growth and accumulation could be the controlling force on the $\mathrm{BCB}$ cycles. Given the period of time represented by the $\mathrm{BCB}$, the facies distribution would be expected to be truly random if autocyclicity were the controlling mechanism. Evidence suggesting that such autocyclic processes operate on timescales of $<10^{3}$ years (Calder and Gibling, 1994), supports an allocyclic sequence development for the cycles within the $\mathrm{BCB}$ rather than autogenic cyclicity.

The recognition of these cycles as sequences and the ability to separate the sequences into conventional systems tracts (LST, TST, HST), rely on subtle indicators, such as tidally influenced fluvial deposits (Facies A3) and thin, discrete horizons of bioturbated estuarine deposits (Facies B3) interpreted as flooding surfaces (Figure 14). If not examined in detail, the $\mathrm{BCB}$ could easily be mistaken for the archetypal amalgamated stacked fluvial deposits characteristic of updip basin margin settings (i.e. Shanley and McCabe, 1993; Miall, 1996).

\subsection{Sequence boundaries}

Major erosion surfaces interpreted as sequence boundaries are defined by the bases of coarse-grained, laterally extensive, braided fluvial sandstones that erode into underlying coastal plain coals. These surfaces can be traced 

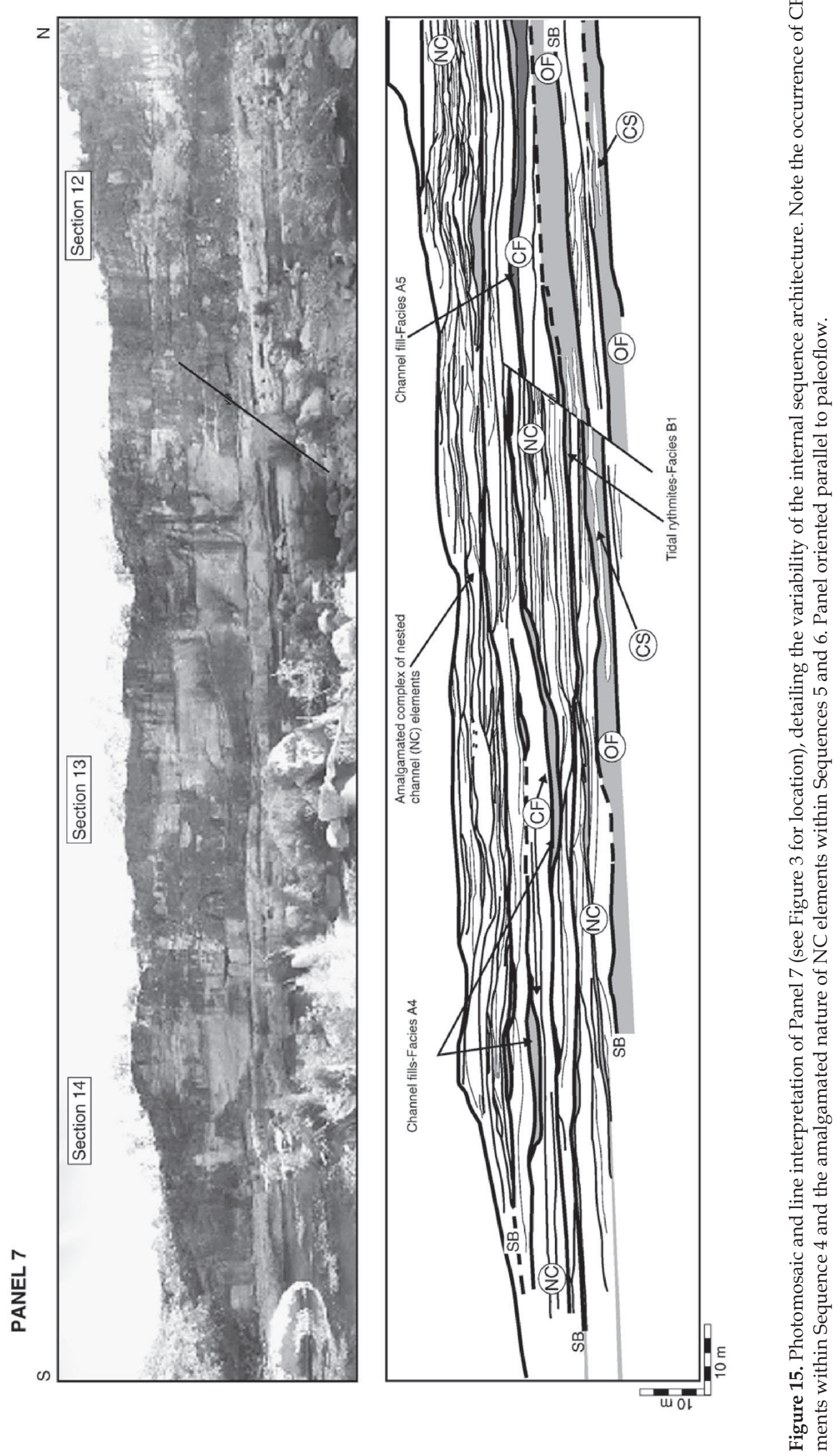
continuously in the cliff exposures over the entire study area, and therefore represent regionally extensive erosional surfaces. In addition, they can be distinguished from other, more local, erosional surfaces caused by autogenic processes. The erosional relief on these surfaces can only be observed locally where channel margins are observed, and is typically $<5 \mathrm{~m}$. There is no evidence that they have any significant regional erosional relief and are more-or-less planar in nature at the scale of several km's (Figure 13).

These surfaces differ from scoured erosional surfaces characteristic of fluvial environments resulting from autogenic processes, because they are more prominent and widespread. The sequence boundaries within the BCB are similar to other interpreted sequence boundaries in alluvial strata (Van Wagoner et al., 1990; Shanley and McCabe, 1991, 1993, 1994; Gibling and Bird, 1994; Olsen et al., 1995; Yoshida et al., 1996), in that there is a sharp juxtaposition between braided fluvial sandstones and carbonaceous coastalplain deposits marking a change in the amount of accommodation space. However, the sequence boundaries within the BCB are planar and show minimal erosional relief, similar to sequence boundaries observed in the Ericson Sandstone by Martinsen et al. (1999). A planar sequence boundary is to be expected in low-gradient settings such as basin margins. Where the slope of the fluvial profile near the coastline is similar to the bathymetric profile of a shallow shelf, only minor fluvial incision will occur and incised valleys tend to be relatively wide (Shanley and McCabe, 1994; Posamentier and Allen, 1999). Under such circumstances the fluvial systems may simply be extended. This is in contrast to areas where there is a distinct difference in slope between the alluvial/coastal plain and shallow marine shelf, which favors valley incision (Shanley and McCabe, 1994; Posamentier and Allen, 1999). Flume studies (Wood et al., 1991; Koss et al., 1994), theoretical models (Schumm, 1993; Posamentier and Allen, 1999), and outcrop studies (Shanley and McCabe, 1991, 1994; Martinsen et al., 1999) suggest that planar sequence boundaries and fluvial sheet sandstones are common in low-accommodation settings during base-level fall and early rise.

\subsection{Flooding surfaces}

As mentioned above, flooding surfaces (FS) within the $\mathrm{BCB}$ are represented by the thin deposits of Facies B3. FS occur as sharp contacts between tidally influenced, alluvial-channel facies and estuarine/coastal embayment facies (Facies B3) marking an increase in water depth. Where FS occur between Facies A3 and B3 (TST deposits) and Facies B1, B2 (HST deposits), they may represent the maximum flooding surface (MFS; Figure 14). A MFS interpretation, however, is tentative: nonetheless, these intervals are interpreted as having formed under conditions of greatest water depths and minimal sediment supply.

\subsection{Sequence architecture}

Sequences show an overall, extensive sheet-like architecture which varies little across the study area (Figure 13). Sequences consist of a basal, sheet-like, braided fluvial sandstone complex predominantly made up of stacked tabular or lenticular NC elements arranged in a multistorey and multilateral framework that erosionally overlies sediments of the underlying sequence (typically OF elements; Figure 15).

Overlying the sandstone complexes are extensive, sheet-like, floodbasin and coastal plain OF lithosomes locally containing LE and CS elements. OF elements contain a mosaic of facies that vary both laterally and vertically, but always begin with Facies B3 at the base, overlain by Facies B2 and B1. OF lithosomes are erosionally overlain by a sheet-like NC sandstone complex that marks the base of the overlying sequence (Figure 15).

\subsubsection{Variation in sequence architecture}

The sequences of the $\mathrm{BCB}$ show variation in internal architecture vertically through the formation. The sequences can be divided on this basis into 4 groups (Sequence 1; Sequences 2, 3; Sequence 4; Sequences 5, 6) within each of which architecture is similar, but between which, architecture differs.

6.3.1.1. Sequence 1 - Sequence 1 is composed entirely of Facies A1, and is markedly different from the overlying sequences. It is typically $11 \mathrm{~m}$ in thickness and thins slightly southward. This sequence consists mostly of SF elements, although some $\mathrm{CH}$ features are also observed. $\mathrm{SF}$ elements are broad and shallow $(2 \times 50 \mathrm{~m})$ and form a complex mosaic that characterizes this basal sequence of the formation.

6.3.1.2. Sequences 2,3 - Sequences 2 and 3 are characterized by the overall architecture outlined above. These sequences contain the best developed OF lithosomes (Figure 15), but this may possibly be the result of bias in data collection due to the fact that they are easily accessed from creek level, whereas other sequences are in most places inaccessible vertical cliff exposures. Only two accretionary elements (DA, LA) have been observed in these lower sequences, where they overlie an 
OF lithosome. The two elements are at the same stratigraphic horizon and they may represent the same architectural feature.

6.3.1.3. Sequence 4 - Sequence 4 is similar to Sequences 2 and 3; however, this sequence contains the vast majority and best preservation of CF elements (Figure 15). As a result of the abnormally higher proportion of $\mathrm{CF}$ elements within this sequence as compared to the other sequences, Sequence 4 has a much higher proportion of mud-to-sand.

6.3.1.4. Sequences 5, 6 - These sequences are similar in overall nature to Sequences 2 and 3; however, there are some key differences. The basal sandstone complexes within these sequences have a much more amalgamated character in comparison to those of underlying sequences (Figure 15). NC elements are laterally restricted and are typically $<100 \mathrm{~m}$ in length. This is in contrast to NC elements of the previous sequences that in some instances measure $>500 \mathrm{~m}$ in length. Observations indicate a general paucity of fine-grained partings between individual NC elements.

Along with NC elements, basal sandstone complexes also consist of LA and DA elements. Accretionary elements typically average $\sim 3 \mathrm{~m}$ in thickness, although in Sequence 6, LA elements measuring 6-7 $\mathrm{m}$ in thickness are observed (Figure 7).

\section{Discussion}

The above architectural analysis highlights several different controlling forces on the sediment body architecture of the Betts Creek alluvial system. The overall sediment body architecture of the BCB was affected by allogenic controls, and we argue that sea level is the only control whose signal can account for the genetic sequence architecture of the formation. The recognition and interpretation of Facies B3 as an estuarine deposit and the subsequent development of a sequence stratigraphic framework for the $\mathrm{BCB}$ demonstrate that changes in relative sea level had a profound control on the overall sediment body architecture of the formation. Given the basin-marginal context and evidence for a steady, slow subsidence regime throughout accumulation of the $\mathrm{BCB}$, it is considered most likely that absolute (eustatically driven) sea-level fluctuations were largely responsible for the observed sequence patterns. While climate has major influences on the stratigraphic architecture of fluvial systems (Fielding and Webb, 1996; Blum and Törnqvist, 2000; Ray and Chakraborty, 2002; Bridge, 2003), and fluvial sys- tems reflect the influence of both sea level and climate change (Blum and Törnqvist, 2000), the effects of sealevel change, in this study, are believed to have overwhelmed any recognizable climatic signature. Poor age constraints would also make any estimates of a climatic signal difficult.

The low-accommodation, basin-marginal setting, the overall lack of evidence to suggest changes in tectonic subsidence rates (stratigraphic discordance, changes in paleocurrent direction, increased soft-sediment deformation, etc.), along with evidence for periodic marineinfluenced conditions argue persuasively for a strong sea-level control on the genetic fluvial architecture. The relatively homogeneous overall sheet-like, sequence architecture, therefore, is reflective of sea-level change and suggests that the magnitude of change responsible for creating these sequences was relatively consistent during the Late Permian. The BCB were deposited at the end of the Late Paleozoic Ice Age, and recent evidence from eastern Australia suggests that during BCB deposition, Gondwana experienced at least two discrete periods of glaciation (Fielding et al., 2006; Birgenheier et al., 2006). It is believed that the sequences within the $B C B$ are the result of glacioeustatic sea-level changes caused by the expansion and contraction of polar ice volumes on Gondwana.

While sea-level change is invoked to explain the sequence architecture, other controls must also be called upon in order to explain the internal variability of the sequences illustrated in previous sections.

The tectonic setting of the Galilee and adjacent Bowen Basins provides insights into one of the controls affecting the internal stratigraphic architecture of the BCB. During the Late Permian, both basins were experiencing a period of foreland loading in response to thrust sheet propagation from the Hunter-Bowen Event (Fielding et al., 2001; Van Heeswijck, 2004). This period of foreland loading is associated with widespread and explosive volcanism in the north-northeastern portion of the Bowen Basin, which is believed to have sourced the volcanic detritus observed in the BCB. Sudden influxes of volcanic debris have been shown to drastically alter fluvial sedimentation patterns in several studies (Besly and Collinson, 1991; Fielding et al., 1993; Nakayama and Yoshikawa, 1997; Kataoka and Nakajo, 2002). This influx of fine-grained material is thought to have increased the preservation of abandoned channel deposits that has resulted in architecture with a higher proportion of $\mathrm{CF}$ elements and a fluvial system with an increased mudstone-to-sandstone proportion as observed in Sequence 4. Braided systems with high mudto-sand proportions have been documented from a variety of tectonic settings including extensional basins 
(Mack and Seager, 1990; Mack and James, 1993), intermontane basins (Lorenz and Nadon, 2002), and foreland basins (Bentham et al., 1993; Willis, 1993; Adams and Battacharya, 2005). While tectonic processes in the basin-marginal setting may not have been an important control on the fluvial style of the $\mathrm{BCB}$, tectonic processes and explosive volcanism in the source area (i.e. the Bowen Basin) may have been (cf. Mack and James, 1993; Lorenz and Nadon, 2002). While the majority of the $\mathrm{BCB}$ has a very low mudstone-to-sandstone proportion, this section of the formation adds to a growing number of examples of low net-to-gross fluvial systems that challenge classic braided fluvial facies models (Walker and Cant, 1984).

The internal architecture of the BCB was also influenced by more localized autogenic controls. The increased amalgamation of channel sandstones observed in the higher sequences (Sequences 5, 6) is believed to be a result of increased rates of avulsion. Considering that avulsion rates are influenced by a number of variables (sedimentation rate, sinuosity increase, base level, climate, tectonic uplift, etc.; see Jones and Schumm, 1999), there are several possible explanations for an increased rate of avulsion in the upper portion of the BCB. However, the most likely explanation is the interplay between changes in base level (sea level in this scenario) and tectonics, and the subsequent effects on sedimentation rates these processes would have caused. Mackey and Bridge (1995) and Heller and Paola (1996) have shown that increased rates in sediment supply increase rates of avulsion frequency. Increased rates of sediment supply caused by periodic explosive volcanism are envisaged to have caused increased topographic relief of channels above the floodplain, which led to a greater increase in avulsion frequency. These increased rates of sediment supply may also explain the increase in channel depth and prevalence of braiding (as indicated by the occurrence of accretionary elements in higher sequences) in this part of the formation.

\section{Conclusions}

The Betts Creek Beds represent deposition on an alluvial/coastal-plain setting and consists of two major facies associations: channel and floodbasin. The channel facies association includes the deposits of low-sinuosity, braided rivers, tidally influenced rivers, and fluvially reworked, pyroclastic deposits. The floodbasin facies association consists of proximal to distal floodplain, swamp/mire, and estuarine/coastal embayment deposits.

The architecture of the formation is characterized by 6 sequences that are each 10-14 $\mathrm{m}$ in thickness, con- densed, and top-truncated. The internal architecture of the sequences is characterized by amalgamated sheetlike, multistorey, multilateral braided fluvial sandstones overlain by estuarine mudstones and coastal-plain carbonaceous shales and coals. The overall sequence architecture was controlled by changes (presumed eustatic) in sea level, while the internal architecture, which is more variable and complex, was the result of a combination of sea level, tectonic, and autogenic controls.

The fact that well-developed, albeit thin and condensed, sequences can be preserved and recognized in a low-accommodation, basin-marginal succession is quite striking. Traditionally, such settings have proved difficult to analyze by sequence stratigraphic methods, because key surfaces are not easily discerned from more local erosional surfaces. The nature of the BCB outcrop and the recognition of discrete marine-influenced units interpreted as flooding surfaces allow for a high-resolution sequence framework to be established in a unit that could easily be mistakenly interpreted as archetypal amalgamated, stacked fluvial deposits characteristic of updip basin-margin settings.

Acknowledgments - The authors would like to thank the reviewers for Sedimentary Geology, whose critical comments considerably improved the quality of this manuscript. This research was supported by the Mr. and Mrs. J. B. Coffman endowment in sedimentary geology at the University of $\mathrm{Ne}$ braska-Lincoln. We would also like to thank the Queensland Parks and Wildlife Service for allowing research to be undertaken and samples collected at Porcupine Creek Gorge.

\section{References}

Adams and Battacharya, 2005 - M. M. Adams and J. P. Battacharya, No change in fluvial style across a sequence boundary, Cretaceous Blackhawk and Castlegate Formations of Central Utah, U.S.A. J. Sediment. Res. 75 (2005), pp. 1038-1051.

Allen, 1982 - J. R. L. Allen, Sedimentary Structures: Their Character and Physical Basis, Elsevier, Amsterdam (1982) 593 pp.

Allen, 1983 - J. R. L. Allen, Studies in fluviatile sedimentation: bars, bar-complexes and sandstone sheets (low-sinuosity braided streams) in the Brownstones (L. Devonian), Welsh Borders, Sediment. Geol. 33 (1983), pp. 237-293.

Allen, 1991 - G. P. Allen, Sedimentary processes and facies in the Gironde estuary: A recent model for macrotidal estuarine systems. In: D. G. Smith, G. E. Reinson, B. A. Zaitlin, and R. A. Rahmani, eds., Clastic Tidal Sedimentology, Memoir Can. Soc. Petrol. Geol. vol. 16 (1991), pp. 29-40.

Anthony, 2004 - D. P. Anthony, A review of recent conventional petroleum exploration and in-field gas reserves growth in the Denison Trough, Queensland. Eastern Australasian Basins Symposium II., Petrol. Explor. Soc. Austr. Adelaide (2004), pp. 276-295.

Bann and Fielding, 2001 - K. L. Bann and C. R. Fielding, Applications of ichnology to hydrocarbon exploration-examples from the Permian of eastern Australia. In: K. C. Hill and T. Bernecker, eds. Eastern Australasian Basins Symposium 2001, Spec. Publ. Petrol. Ex- 
plor. Soc. Austr., AustIMM, Melbourne (2001), pp. 603-612.

Bann and Fielding, 2004 - K. L. Bann and C. R. Fielding, An integrated ichnological and sedimentological comparison of non-deltaic shoreface and subaqueous delta deposits in the Permian reservoir units of Australia. In: D. McIlroy, ed., The Application of Ichnology to Palaeoenvironmental and Stratigraphic Analysis, Geol. Soc. Spec. Publ. vol. 228 (2004), pp. 273-307.

Bann et al., 2004 - K. L. Bann, C. R. Fielding, J. A. MacEachern, and S. C. Tye, Differentiation of estuarine and offshore marine deposits using integrated ichnology and sedimentology: Permian Pebbley Beach Formation, Sydney Basin, Australia. In: D. McIlroy, ed., The Application of Ichnology to Palaeoenvironmental and Stratigraphic Analysis, Geol. Soc. Spec. Publ. vol. 228 (2004), pp. 179-212.

Bentham et al., 1993 - P. A. Bentham, P. J. Talling, and D. W. Burbank, Braided stream and floodplain deposition in a rapidly aggrading basin: The Escanilla Formation, Spanish Pyrenees. In: J. L. Best and C. S. Bristow, eds., Braided Rivers, Geol. Soc. Spec. Publ. vol. 75 (1993), pp. 177-194.

Besly and Collinson, 1991 • B. M. Besly and J. D. Collinson, Volcanic and tectonic controls of lacustrine and alluvial sedimentation in the Stephanian coal-bearing sequence of the Malpas-Sort Basin, Catalonian Pyrenees, Sedimentology 38 (1991), pp. 3-26.

Beynon and Pemberton, 1992 - B. M. Beynon and S. G. Pemberton, Ichnological signature of a brackish water deposit: An example from the Lower Cretaceous Grand Rapids Formation, Cold Lake Oil Sands area, Alberta. In: S. G. Pemberton, ed., Applications of Ichnology to Petroleum Exploration; A Core Workshop, Soc. Econ. Paleont. Miner. Core Workshop vol. 17 (1992), pp. 199-222.

Birgenheier et al., 2006 • L. T. Birgenheier, C. R. Fielding, T. D. Frank, M. C. Rygel, and J. Roberts, Lithologic consequences of glacially influenced deposition: A case study from the Late Paleozoic of New South Wales, Australia, AAPG Annual Convention Abstracts (2006), p. 10.

Blum and Törnqvist, 2000 - M. D. Blum and T. E. Törnqvist, Fluvial response to climate and sea-level change: A review and look forward, Sedimentology 47 (2000), pp. 2-48.

Bohacs and Suter, 1997 - K. Bohacs and J. Suter, Sequence stratigraphic distribution of coaly rocks: Fundamental controls and paralic examples, AAPG Bull. 81 (1997), pp. 1612-1639.

Boothroyd and Ashley, 1975 - J. C. Boothroyd and G. M. Ashley, Process, bar morphology, and sedimentary structures on braided outwash fans, northeastern Gulf of Alaska. In: A. V. Jopling and B. C. McDonalds, eds., Glaciofluvial and Glaciolacustrine Sedimentation, Spec. Publ. Soc. Econ. Paleont. Miner. vol. 23 (1975), pp. 193-222.

Bridge, 1985 - J. S. Bridge, Paleochannel patterns inferred from alluvial deposits: A critical evaluation, J. Sediment. Petrol. 55 (1985), pp. 579-589.

Bridge, 1997 J. S. Bridge, Thickness of sets of cross strata and planar strata as a function of formative bed-wave geometry and migration, and aggradation rate, Geology 25 (1997), pp. 971-974.

Bridge, 2003 - J. S. Bridge, Rivers and Floodplains: Forms, Processes, and the Sedimentary Record, Blackwell, Oxford (2003), 491 pp.

Bridge and Tye, 2000 - J. S. Bridge and R. S. Tye, Interpreting the dimensions of ancient fluvial channel bars, channels, and channel belts from wireline-logs and cores, AAPG Bull. 84 (2000), pp. 1205-1228.

Bristow and Best, 1993 - C. S. Bristow and J. L. Best, Braided rivers: Perspectives and problems. In: J. L. Best and C. S. Bristow, eds., Braided Rivers, Geol. Soc. Spec. Publ. vol. 75 (1993), pp. 291-304.

Burst, 1965 - J. F. Burst, Subaqueously formed shrinkage cracks in clay, J. Sediment. Petrol. 35 (1965), pp. 348-353.

Calder and Gibling, $1994 \cdot$ J. H. Calder and M. R. Gibling, The Euramerican Coal Province: Controls on Late Paleozoic peat accumulation, Palaeogeogr. Palaeoclim. Palaeoecol. 106 (1994), pp. 1-21.

Collinson, 1996 - J. D. Collinson, Alluvial sediments. In: H. G. Reading, ed., Sedimentary Environments: Processes, Facies, and Stratigraphy, Blackwell Science, Oxford (1996), pp. 37-83.

De Caritat and Braun, 1992 - P. De Caritat and J. Braun, Cyclic devel- opment of sedimentary basins at convergent plate margins: structural and tectono-thermal evolution of some Gondwana basins of eastern Australia, J. Geodyn. 16 (1992), pp. 241-282.

Ekdale et al., 1984 - A. A. Ekdale, R. G. Bromley, and S. G. Pemberton, Ichnology; The use of trace fossils and stratigraphy, Soc. Econ. Paleont. Miner. Short Course vol. 15 (1984), 317 pp.

Evans, 1967 - P. R. Evans, Upper Carboniferous and Permian palynological stages and their distribution in eastern Australia. Record 1967/99, Bur. Min. Res. Geol. Geophys., Aust. (1967).

Evans, 1980 • P. R. Evans, Geology of the Galilee Basin. In: R. A. Henerson and P. J. Stephenson, eds., The Geology and Geophysics of Northeastern Australia, Geolog. Soc. Aust. (1980), pp. 299-305.

Farrell, 1987 - K. M. Farrell, Sedimentology and facies architecture of overbank deposits of the Mississippi River, False River region, Louisiana. In: F. G. Ethridge, R. M. Flores, and M. D. Harvey, eds., Recent Developments in Fluvial Sedimentology, Spec. Publ. Soc. Econ. Paleont. Miner. vol. 39 (1987), pp. 111-120.

Fielding, 1987 - C. R. Fielding, Coal depositional models for deltaic and alluvial plain sequences, Geology 15 (1987), pp. 661-664.

Fielding and Webb, 1996 - C. R. Fielding and J. A. Webb, Facies and cyclicity of the Late Permian Bainmedart Coal Measures in the Northern Prince Charles Mountains, MacRobertson Land, Antarctica, Sedimentology 43 (1996), pp. 295-322.

Fielding et al., 1993 - C. R. Fielding, A. J. Falkner, and S. G. Scott, Fluvial response to foreland basin overfilling: The Late Permian Rangal Coal Measures in the Bowen Basin, Queensland, Australia, Sediment. Geol. 85 (1993), pp. 475-497.

Fielding et al., 2000 - C. R. Fielding, T. R. Naish, K. J. Woolfe, and M. A. Lavelle, Facies analysis and stratigraphy of CRP-2/2A, Victoria Land Basin, Antarctica, Terra Antarctica 7 (2000), pp. 323-338.

Fielding et al., 2001 - C. R. Fielding, R. Sliwa, R. J. Holcombe, and A. T. Jones, A new paleogeographic synthesis for the Bowen, Gunneday, and Sydney basins of Eastern Australia. In: K. C. Hill and T. Bernecker, eds., Eastern Australasian Basins Symposium, Spec. Publ. Petrol. Explor. Soc. Austr., AustIMM, Melbourne (2001), pp. 269-279.

Fielding et al., 2006 • C. R. Fielding, K. L. Bann, J. A. MacEachern, T. Frank, and M. C. Rygel, Stratigraphic stacking patterns through a protracted Icehouse interval disclose alternating glacial and nonglacial periods: The Permian of Eastern Australia, AAPG Annual Convention Abstracts (2006), p. 32.

Gelfenbaum, 1983 • G. Gelfenbaum, Suspended sediment response to semidiurnal and fortnightly tidal variations in a mesotidal estuary: Columbia River, U. S. A., Mar. Geol. 52 (1983), pp. 39-57.

Gibbs et al., 2002 - M. T. Gibbs, P. A. Rees, J. E. Kutzbach, A. M. Ziegler, P. J. Behling, and D. B. Rowley, Simulations of Permian climate and comparisons with climate-sensitive sediments, J. Geol. 110 (2002), pp. 33-55.

Gibling and Bird, 1994 - M. R. Gibling and D. J. Bird, Late Carboniferous cyclothems and alluvial paleovalleys in the Sydney Basin, Nova Scotia, Geol. Soc. Amer. Bull. 106 (1994), pp. 105-117.

Hawkins, 1976 - P. J. Hawkins, Facies analysis and economic significance of the Late Permian strata in the northern Galilee Basin: Queensland Govt, Min. J. 77 (1976), pp. 15-32.

Hawkins, 1978 - P. J. Hawkins, Galilee Basin-Review of petroleum prospects, Queensl. Gov. Min. J. 79 (1978), pp. 96-112.

Hawkins and Green, 1993 • P. J. Hawkins and P. M. Green, Exploration results, hydrocarbon potential, and future strategies for the northern Galilee Basin, APEA J. 33 (1993), pp. 280-296.

Heller and Paola, 1996 - P. L. Heller and C. Paola, Downstream changes in alluvial architecture: an exploration of controls on channel stacking patterns, J. Sediment. Res. 66 (1996), pp. 297-306.

Howard and Frey, 1973 - J. D. Howard and R. W. Frey, Characteristic physical and biogenic sedimentary structures in Georgia estuaries, AAPG Bull. 57 (1973), pp. 1159-1184.

Hjellbakk, 1997 - A. Hjellbakk, Facies and fluvial architecture of a high-energy braided river; The upper Proterozoic Seglodden Member, Varanger Peninsula, Northern Norway, Sediment. Geol. 
144 (1997), pp. 131-161.

Jones and Schumm, 1999 - L. S. Jones and S. A. Schumm, Causes of avulsion: An overview. In: N. D. Smith and J. Roger, eds., Fluvial sedimentology VI, Spec. Publ. Intern. Assoc. Sediment. vol. 28 (1999), pp. 171-178.

Jorgensen and Fielding, 1996 • P. J. Jorgensen and C. R. Fielding, Facies architecture of alluvial floodbasin deposits; Three-dimensional data from the Upper Triassic Callide Coal Measures of east-central Queensland, Australia, Sedimentology 43 (1996), pp. 479-495.

Jorgensen and Fielding, 1999 • P. J. Jorgensen and C. R. Fielding, Debris-flow deposits in an alluvial-plain succession: The Upper Triassic Callide Coal Measures of Queensland, Australia, J. Sediment. Res. 69 (1999), pp. 1027-1040.

Karpetta, 1993 - W. P. Karpetta, Sedimentology and gravel bar morphology in an Archaean braided river sequence: The Witpan Conglomerate Member (Witwatersrand Supergroup) in the Welkom Goldfield, South Africa. In: J. L. Best and C. S Bristow, eds., Braided Rivers, Geol. Soc. Spec. Publ. vol. 75 (1993), pp. 369-388.

Kataoka and Nakajo, 2002 - K. Kataoka and T. Nakajo, Volcaniclastic resedimentation in distal fluvial basins induced by large-volume explosive volcanism: The Ebisutoge-Fukuda tephr, Plio-Pleistocene boundary, central Japan, Sedimentology 49 (2002), pp. 319-334.

Kidwell, 1997 - S. M. Kidwell, Anatomy of extremely thin marine sequences landward of a passive-margin hinge zone: Neogene Calvert Cliffs succession, Maryland, USA, J. Sediment. Res. 67 (1997), pp. 322-340.

Koss et al., 1994 - J. E. Koss, F. G. Ethridge, and S. A. Schumm, An experimental study of the effects of base-level change on fluvial, coastal plain, and shelf systems, J. Sediment. Res. 66 (1994), pp. 354-363.

Lang et al., 2001 • S. C. Lang, P. Grech, R. Root, A. Hill, and D. Harrison, The application of sequence stratigraphy to exploration and reservoir development in the Cooper-Eromanga-Bowen-Surat basin system, APPEA J. 41 (2001), pp. 223-250.

Leclair and Bridge, 2001 - S. F. Leclair and J. S. Bridge, Quantitative interpretation of sedimentary structures formed by river dunes, J. Sediment. Res. 71 (2001), pp. 713-716.

Leclair et al., 1997 • S. F. Leclair, J. S. Bridge, and F. Wang, Preservation of cross-strata due to the migration of subaqueous dunes over aggrading and non-aggrading beds: Comparison of experimental data with theory, Geosci. Can. 24 (1997), pp. 55-66.

Leeder, 1987 - M. R. Leeder, Sediment deformation structures and the palaeotectonic analysis of sedimentary basins, with a case-study from the Carboniferous of northern England. In: M. E. Jones and R. M. F. Preston, eds., Deformation of Sediments and Sedimentary Rocks, Geol. Soc. Spec. Publ. vol. 29 (1987), pp. 137-146.

Lorenz and Nadon, 2002 - J. C. Lorenz and G. C. Nadon, Braidedriver deposits in a muddy depositional setting: The Molina Member of the Wasatch Formation (Paleogene), west-central Colorado, USA, J. Sediment. Res. 72 (2002), pp. 376-385.

Mack and James, 1993 - G. H. Mack and W. C. James, Control of basin symmetry on fluvial lithofacies, Camp Rice and Palomas formations (Plio-Pleistocene), southern Rio Grande Rift, USA. In: M. Marzo and C. Puigdefabregas, eds., Alluvial Sedimentation, Spec. Publ. Intern. Assoc. Sediment. vol. 17 (1993), pp. 439-449.

Mack and Seager, 1990 • G. H. Mack and W. R. Seager, Tectonic control on facies distribution of the Camp Rice and Palomas formations (Plio-Pleistocene), southern Rio Grande Rift, USA, Geol. Soc. Amer. Bull. 102 (1990), pp. 45-53.

Mackey and Bridge, 1995 - S. D. Mackey and J. S. Bridge, Three dimensional model of alluvial stratigraphy: Theory and application, J. Sediment. Res. 65 (1995), pp. 7-31.

Major, 1997 • J. J. Major, Depositional processes in large-scale debris flow experiments, J. Geol. 105 (1997), pp. 345-366.

Martinsen et al., 1999 • O. J. Martinsen, A. Ryseth, W. Helland-Hansen, H. Flesche, G. Torkildsen, and S. Idil, Stratigraphic base level and fluvial architecture: Ericson Sandstone (Campanian), Rock
Springs Uplift, SW Wyoming, U. S. A., Sedimentology 46 (1999), pp. 235-259.

Massari et al., 1993 - F. Massari, D. Mellere, and C. Doglion, Cyclicity in non-marine foreland-basin sedimentary fill: The Messinian conglomerate-bearing succession of the Venetian Alps (Italy). In: M. Marzo and C. Puigdefabregas, eds., Alluvial Sedimentation, Spec. Publ. Intern. Assoc. Sediment. vol. 17 (1993), pp. 501-520.

McCabe, 1984 - P. J. McCabe, Depositional environments of coal and coal-bearing strata. In: R. A. Rahmani and R. M. Flores, eds., Sedimentology of Coal-bearing Sequences, Spec. Publ. Intern. Assoc. Sediment. vol. 7 (1984), pp. 13-42.

Miall, 1977 - A. D. Miall, A review of the braided river depositional environment, Earth-Sci. Rev. 13 (1977), pp. 1-62.

Miall, 1985 - A. D. Miall, Architectural-element analysis: A new method of facies analysis applied to fluvial deposits, Earth-Sci. Rev. 22 (1985), pp. 261-308.

Miall, 1988 - A. D. Miall, Architectural elements and bounding surfaces in fluvial deposits: Anatomy of the Kayenta Formation (Lower Jurassic), southwest Colorado, Sediment. Geol. 55 (1988), pp. 233-262.

Miall, 1996 - A. D. Miall, The Geology of Fluvial Deposits: Sedimentary Facies, Basin Analysis, and Petroleum Geology, Springer-Verlag, Berlin (1996), $586 \mathrm{pp}$.

Michaelson et al., 2000 • P. Michaelson, R. A. Henderson, P. J. Crosdale, and S. O. Mikkelsen, Facies architecture and depositional dynamics of the Upper Permian Rangal coal measures, Bowen Basin, Australia, J. Sediment. Res. 70 (2000), pp. 879-895.

Middleton and Hunt, $1989 \cdot$ M. F. Middleton and J. W. Hunt, Influence of tectonics on Permian coal-rank patterns in Australia, Int. J. Coal Geol. 13 (1989), pp. 391-411.

Moncrieff, 1989 - A. C. M. Moncrieff, Classification of poorly sorted sedimentary rocks, Sediment. Geol. 65 (1989), pp. 191-194.

Mothes et al., 1998 - P. A. Mothes, M. L. Hall, and R. J. Janda, The enormous Chillos Valley lahar: An ash-flow-generated debris flow from Cotopaxi volcano, Equador, Bull. Volcanol. 59 (1998), pp. 233-244.

Mulder and Alexander, 2001 • T. Mulder and J. Alexander, The physical character of subaqueous sedimentary density flows and their deposits, Sedimentology 48 (2001), pp. 269-299.

Naish and Kamp, 1997 • T. R. Naish and P. J. J. Kamp, Sequence stratigraphy of sixth-order (41 k. y.) Pliocene-Pleistocene cyclothems, Wanganui Basin, New Zealand: A case for the regressive systems tract, Geol. Soc. Amer. Bull. 109 (1997), pp. 978-999.

Nakayama and Yoshikawa, 1997 - K. Nakayama and S. Yoshikawa, Depositional processes of primary to reworked volcaniclastics on an alluvial plain; An example from the Lower Pliocene Ohta tephra bed of the Tokai Group, central Japan, Sediment. Geol. 107 (1997), pp. 211-229.

Nemec and Steel, 1984 - W. Nemec and R. J. Steel, Alluvial and coastal conglomerates; Their significant features and some comments on gravelly mass-flow deposits. In: E. H. Koster, ed., Sedimentology of Gravels and Conglomerates, Memoir Can. Soc. Petrol. Geol. vol. 10 (1984), pp. 1-31.

Olsen et al., 1995 • T. Olsen, R. Steel, K. Høgseth, T. Skar, and S. L. Røe, Sequential architecture in a fluvial succession: Sequence stratigraphy in the Upper Cretaceous Mesa Verde Group, Price Canyon, Utah, J. Sediment. Res., Sect. B Stratigr. Glob. Stud. 65 (1995), pp. 265-280.

Owen, 1996 - G. Owen, Experimental soft-sediment deformation; Structures formed by the liquefaction of unconsolidated sands and some ancient examples, Sedimentology 43 (1996), pp. 279-293.

Pashin and Gastaldo, 2004 - J. C. Pashin and R. A. Gastaldo, eds., Sequence Stratigraphy, Paleoclimate, and Tectonics of Coal-Bearing Strata, AAPG Stud. Geol. vol. 51 (2004), 238 pp.

Pemberton et al., 1992 • S. G. Pemberton, J. A. MacEachern, and R. W. Frey, Trace fossil facies models: Environmental and allostratigraphic significance. In: R. G. Walker and N. P. James, eds., Facies Models: Response to Sea Level Change, Geol. Assoc. Can. (1992), 
pp. 47-72.

Pierson and Scott, 1985 - T. C. Pierson and K. M. Scott, Downstream dilution of a lahar; Transition from debris flow to hyperconcentrated streamflow, Water Resour. Res. 21 (1985), pp. 1511-1524.

Plummer and Gostin, 1981 • P. S. Plummer and V. A. Gostin, Shrinkage cracks: Desiccation or synaeresis, J. Sediment. Petrol. 51 (1981), pp. 1147-1156.

Posamentier and Allen, 1999 • H. W. Posamentier and G. P. Allen, Siliciclastic Sequence Stratigraphy - Concepts and Applications, Soc. Econ. Paleont. Miner. Conc. Sediment. Paleont. 7 (1999) 210 pp.

Ramos et al., 1986 - A. Ramos, A. Sopeña, and M. Perez-Arlucea, Evolution of Buntsandstein fluvial sedimentation in the northwest Iberian Ranges (central Spain), J. Sediment. Petrol. 56 (1986), pp. 862-875.

Ray and Chakraborty, 2002 - S. Ray and T. Chakraborty, Lower Gondwana fluvial succession of the Pench-Kanhan valley, India: Stratigraphic architecture and depositional controls, Sediment. Geol. 151 (2002), pp. 243-271.

Reinfelds and Nanson, 1993 - I. Reinfelds and G. Nanson, Formation of braided river floodplains, Waimakariri, New Zealand, Sedimentology 40 (1993), pp. 1113-1127.

Røe, 1987 - S.-L. Røe, Cross-strata and bedforms of probable dune to upper-stage plane-bed origin from a Late Precambrian fluvial sandstone, northern Norway, Sedimentology 34 (1987), pp. 89-101.

Røe and Hermansen, 1993 - S.-L. Røe and M. Hermansen, Processes and products of large, Late Precambrian sand rivers in northern Norway. In: M. Marzo and C. Puigdefabregas, eds., Alluvial Sedimentation, Spec. Publ. Intern. Assoc. Sediment. vol. 17 (1993), pp. 151-166.

Røe and Hermansen, 2006 - S.-L. Røe and M. Hermansen, New aspects of deformed cross-strata in fluvial sandstones: Examples from Neoproterozoic formations in northern Norway, Sediment. Geol. 186 (2006), pp. 283-293.

Rust, 1978 - B. R. Rust, Depositional models for braided alluvium. In: A. D. Miall, ed., Fluvial Sedimentology, Memoir Can. Soc. Petrol. Geol. vol. 5 (1978), pp. 605-625.

Rust, 1984 - B. R. Rust, Proximal braidplain deposits in the Middle Devonian Malbaie Formation of eastern Gaspé, Quebec, Canada, Sedimentology 31 (1984), pp. 675-695.

Saunderson and Lockett, 1983 - H. C. Saunderson and F. P. J. Lockett, Flume experiments on bedforms and structures at the duneplane bed transition. In: J. D. Collinson and J. Lewin, eds., Modern and Ancient Fluvial Systems, Spec. Publ. Intern. Assoc. Sediment. vol. 6 (1983), pp. 49-58.

Schumm, 1993 - S. A. Schumm, River response to baselevel change: Implications for sequence stratigraphy, J. Geol. 101 (1993), pp. 279-294.

Scott and Hawkins, 1992 - S. G. Scott and P. J. Hawkins, Coal geology of the northern Galilee Basin and its implications for coalseam methane investigations. In: B. B. Beamish and P. D. Gamson, eds., Symposium on Coalbed Methane Research and Development in Australia vol. 5 (1992), pp. 85-102.

Shanley and McCabe, 1991 - K. W. Shanley and P. J. McCabe, Predicting facies architecture through sequence stratigraphy - An example from the Kaiparowits Plateau, Utah, Geology 19 (1991), pp. 742-745.

Shanley and McCabe, 1993 - K. W. Shanley and P. J. McCabe, Alluvial architecture in a sequence stratigraphic framework: A case history from the Upper Cretaceous of southern Utah, USA. In: S. S. Flint and I. D. Bryant, eds., The Geological Modeling of Hydrocarbon Reservoirs and Outcrop Analogues, Spec. Publ. Intern. Assoc. Sediment. vol. 15 (1993), pp. 21-56.

Shanley and McCabe, 1994 - K. W. Shanley and P. J. McCabe, Perspectives on the sequence stratigraphy of continental strata, $A A P G$ Bull. 78 (1994), pp. 544-568.

Simons et al., 1965 - D. B. Simons, E. V. Richardson and C. L. Nordin Jr., Sedimentary structures generated by flow in alluvial channels.
In: G. V. Middleton, ed., Primary Sedimentary Structures and their Hydrodynamic Interpretation, Spec. Publ. Soc. Econ. Paleont. Miner. vol. 12 (1965), pp. 84-115.

Smith, 1974 - N. D. Smith, Sedimentology and bar formation in the upper Kicking Horse River, a braided outwash stream, J. Geol. 81 (1974), pp. 205-223.

Smith, 1986 - G. A. Smith, Coarse-grained nonmarine volcaniclastic sediment: terminology and depositional process, Geol. Soc. Amer. Bull. 97 (1986), pp. 1-10.

Smith, $1990 \cdot$ S. A. Smith, The sedimentology and accretionary styles of an ancient gravel-bed stream: The Budleigh Salterton Pebble Beds (Lower Triassic), southwest England, Sediment. Geol. 67 (1990), pp. 199-219.

Smith and Lowe, 1991 - G. A. Smith and D. R. Lowe, Lahars: Volcano-hydrologic events and deposition in the debris flow-hyperconcentrated flow continuum. In: R. V. Fisher and G. A. Smith, eds., Sedimentation in Volcanic Settings, Spec. Publ. Soc. Econ. Paleont. Miner. vol. 45 (1991), pp. 59-70.

Tye and Coleman, $1989 \cdot$ R. S. Tye and J. M. Coleman, Depositional processes and stratigraphy of fluvially dominated lacustrine deltas; Mississippi delta plain, J. Sediment. Petrol. 59 (1989), pp. 973-996.

Van Heeswijck, 2004 - A. Van Heeswijck, The structure and hydrocarbon potential of the northern Drummond Basin and northeastern Galilee Basin, central Queensland, Australia, Eastern Australasian Basins Symposium II. Petrol. Explor. Soc. Austr. Adelaide (2004), pp. 319-330.

Van Wagoner et al., 1988 • J. C. Van Wagoner, H. W. Posamentier, R. M. Mitchum, P. R. Vail, J. F. Sarg, T. S. Loutit, and J. Hardenbol, An overview of the fundamentals of sequence stratigraphy and key definitions. In: C. K. Wilgus, B. S. Hastings, C. G. St. C. Kendall, H. W. Posamentier, C. A. Ross, and J. C. Van Wagoner, eds., Sea Level Changes - An Integrated Approach, Spec. Publ. Soc. Econ. Paleont. Miner. vol. 42 (1988), pp. 35-39.

Van Wagoner et al., 1990 • J. C. Van Wagoner, R. M. Mitchum, K. M. Campion, and V. D. Rahmanian, Siliciclastic Sequence Stratigraphy in Well Logs, Cores, and Outcrops: Concepts for High-Resolution Correlation of Time and Facies, AAPG Meth. Explor. Ser. vol. 7 (1990), 63 pp.

Veevers et al., 1982 - J. J. Veevers, J. G. Jones and C. M. Powell, Tectonic framework of Australia's sedimentary basins, APEA J. 22 (1982), pp. 283-300.

Vine, 1976 - R. R. Vine, Galilee Basin. In: R. B. Leslie, H. J. Evans, and C. L. Knight, eds., Economic Geology of Australia and Papua New Guinea, Australas, Inst. Min. Metal. AIMM Monograph Series vol. 7 (1976), pp. 316-321.

Vine and Paine, 1974 - R. R. Vine and A. G. L. Paine, Hughenden Queensland, 1:250,000 Geological Series Sheet SG/55-1, Explanatory Notes, Bur. Min. Res. Geol. Geophys. Aust. (1974), 39 pp.

Walker and Cant, 1984 - R. G. Walker and D. J. Cant, Sandy fluvial systems. In: R. G. Walker, ed., Facies Models (2nd edition), Geosci. Can. Reprint Series vol. 1 (1984), pp. 71-89.

White, in press - M. E.White, in press. 1963 plant fossil collections from Hughenden area, Great Artesian Basin. Record 1964/64 Bur. Min. Res. Geol. Geophys. Aust.

Williams and Rust, 1969 • P. F. Williams and B. R. Rust, The sedimentology of a braided river, J. Sediment. Petrol. 39 (1969), pp. 649-679.

Willis, 1993 - B. J. Willis, Ancient river systems in the Himalayan foredeep, Chinji Village area, northern Pakistan, Sediment. Geol. 88 (1993), pp. 1-76.

Wood et al., 1991 - L. J. Wood, F. G. Ethridge, and S. A. Schumm, Influence of subaqueous shelf angle on coastal plain-shelf slope systems: An experimental approach, AAPG Bull. 74 (1991), p. 1349.

Yoshida et al., 1996 - S. Yoshida, A. Willis, and A. D. Miall, Tectonic control of nested sequence architecture in the Castlegate Sandstone (Upper Cretaceous), Book Cliffs, Utah, J. Sediment. Res. 66 (1996), pp. 737-748. 